\title{
Dynamics and fate of blue carbon in a mangrove-seagrass seascape: influence of landscape configuration and land-use change
}

\author{
Maria E. Asplund (D) Martin Dahl • Rashid O. Ismail • Ariane Arias-Ortiz • \\ Diana Deyanova · João N. Franco • Linus Hammar • Arielle I. Hoamby • \\ Hans W. Linderholm • Liberatus D. Lyimo - Diana Perry • Lina M. Rasmusson • \\ Samantha N. Ridgway • Gloria Salgado Gispert • Stéphanie D’Agata • \\ Leah Glass · Jamal Angelot Mahafina • Volanirina Ramahery • \\ Pere Masque • Mats Björk • Martin Gullström
}

Received: 3 May 2020/ Accepted: 10 February 2021 / Published online: 1 March 2021

(C) The Author(s) 2021

\begin{abstract}
Context Seagrass meadows act as efficient natural carbon sinks by sequestering atmospheric $\mathrm{CO}_{2}$ and through trapping of allochthonous organic material, thereby preserving organic carbon $\left(\mathrm{C}_{\text {org }}\right)$ in their sediments. Less understood is the influence of landscape configuration and transformation (land-use change) on carbon sequestration dynamics in coastal seascapes across the land-sea interface.
\end{abstract}

Supplementary Information The online version contains supplementary material available at https://doi.org/10.1007/ s10980-021-01216-8.

M. E. Asplund $(\bowtie) \cdot$ D. Deyanova

Department of Biological and Environmental Sciences,

University of Gothenburg, Kristineberg,

Fiskebäckskil, Sweden

e-mail: maria.asplund@gu.se

M. Dahl · R. O. Ismail · M. Björk

Department of Ecology, Environment and Plant Sciences,

Stockholm University, Stockholm, Sweden

R. O. Ismail

Institute of Marine Sciences, University of Dar es Salaam,

Zanzibar, Tanzania

A. Arias-Ortiz $\cdot$ P. Masque

Departament de Física and Institut de Ciència i

Tecnologia Ambientals, Universitat Autònoma de

Barcelona, Bellaterra, Spain
Objectives We explored the influence of landscape configuration and degradation of adjacent mangroves on the dynamics and fate of $\mathrm{C}_{\text {org }}$ in seagrass habitats. Methods Through predictive modelling, we assessed sedimentary $\mathrm{C}_{\text {org }}$ content, stocks and source composition in multiple seascapes (km-wide buffer zones) dominated by different seagrass communities in northwest Madagascar. The study area encompassed seagrass meadows adjacent to intact and deforested mangroves.

Results The sedimentary $\mathrm{C}_{\text {org }}$ content was influenced by a combination of landscape metrics and inherent habitat plant- and sediment-properties. We found a strong land-to-sea gradient, likely driven by

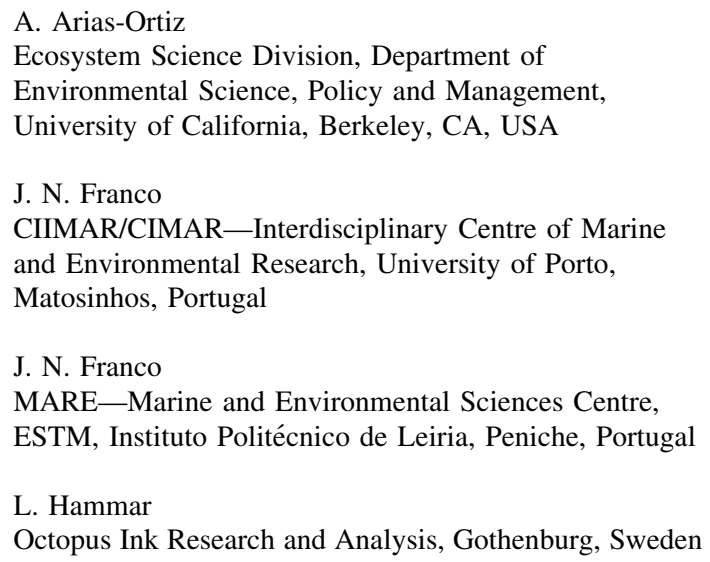


hydrodynamic forces, generating distinct patterns in sedimentary $\mathrm{C}_{\text {org }}$ levels in seagrass seascapes. There was higher $\mathrm{C}_{\text {org }}$ content and a mangrove signal in seagrass surface sediments closer to the deforested mangrove area, possibly due to an escalated export of $\mathrm{C}_{\text {org }}$ from deforested mangrove soils. Seascapes comprising large continuous seagrass meadows had higher sedimentary $\mathrm{C}_{\text {org }}$ levels in comparison to more diverse and patchy seascapes.

Conclusion Our results emphasize the benefit to consider the influence of seascape configuration and connectivity to accurately assess $\mathrm{C}_{\text {org }}$ content in coastal habitats. Understanding spatial patterns of variability and what is driving the observed patterns is useful for identifying carbon sink hotspots and develop management prioritizations.

Keywords Seascape connectivity - Land-sea interface $\cdot$ Mangrove deforestation - Seagrass meadows $\cdot$ Sedimentary carbon storage

\section{Introduction}

The configuration of landscape mosaics strongly influences the strength and spatial patterning of

\section{A. I. Hoamby · J. A. Mahafina Institut Halieutique et des Sciences Marines, de l'Université de Toliara, Toliara, Madagascar}

\section{A. I. Hoamby · S. D'Agata}

Wildlife Conservation Society, Villa Ifanomezantsoa

Soavimbahoaka, Antananarivo, Madagascar

\section{H. W. Linderholm · L. M. Rasmusson}

Regional Climate Group, Department of Earth Sciences, University of Gothenburg, Gothenburg, Sweden

\section{D. Lyimo}

Department of Biology, University of Dodoma, Dodoma, Tanzania

\section{Perry}

Department of Aquatic Resources, Institute of Marine Research, Swedish University of Agricultural Sciences, Lysekil, Sweden

S. N. Ridgway · G. Salgado Gispert · P. Masque School of Science and Centre for Marine Ecosystems Research, Edith Cowan University, Joondalup, Australia ecological processes (Wiens 1995), which may be further affected in landscapes modified by human activities (Fischer and Lindenmayer 2007). Land-use changes are fundamentally restructuring, altering and redeveloping our biosphere while providing human benefits (Foley et al. 2005). In the highly productive coastal environment, habitat composition and connectivity across land-sea gradients control principal processes that in turn are subject to global environmental change (Grober-Dunsmore et al. 2009; Olesen et al. 2018). Today, human dependence on coastal resources is constantly growing as population density increases (Crossland et al. 2005; Pittman et al. 2019), inducing significant pressure from anthropogenic activities within the land-sea interface (Sloan et al. 2007). To accurately address the strength and spatial patterning of ecological processes in the complex coastal environment, it is hence particularly important to understand the joint effect of landscape configuration, land-use change and ecosystem degradation.

The coastal environment encompasses many vegetation-covered habitats that due to their high productivity and efficiency in trapping and storing organic material play an important role as natural carbon sinks, thereby safeguarding critical climate regulation services (Mcleod et al. 2011). Mangrove forests and seagrass meadows are key habitats widely distributed

\section{S. D’Agata}

Department of Earth and Environmental Sciences,

Macquarie University, Sydney, Australia

L. Glass

Blue Ventures Conservation, Villa Bella Fiharena,

Toliara, Madagascar

V. Ramahery

Nexus Madagascar Company, Toliara, Madagascar

P. Masque

International Atomic Energy Agency,

Principality of Monaco, Monaco

M. Gullström

School of Natural Sciences, Technology and

Environmental Studies, Södertörn University, Huddinge,

Sweden 
in tropical and subtropical coastal seascapes (Short et al. 2007; Hamilton and Casey 2016) and considered among the most important, so called, "blue carbon" habitats that mitigate climate change through a high sequestration of atmospheric $\mathrm{CO}_{2}$ (Mcleod et al. 2011; Serrano et al. 2019). The creation process for longterm storage of carbon (Smith 1981; Mateo et al. 1997; Gonneea et al. 2004) and the levels of organic matter accumulation in mangrove- and seagrass-sediments depend on factors operating on different scales, including primary production (Kristensen et al. 2008; Duarte et al. 2010), contemporary environmental conditions and benthic processes (Marbà et al. 2006; Kristensen et al. 2008), habitat configuration and composition (e.g. size, patchiness and edge perimeter; Ricart et al. 2015a, 2017; Oreska et al. 2017), allochthonous input from nearby environments, such as rivers and adjacent coastal habitats (Kennedy et al. 2010; Saintilan et al. 2013; Ricart et al. 2020), and removal of particulate and dissolved organic material due to export from coastal habitats to shelf and open-ocean waters (Alongi et al. 1989; Duarte and Krause-Jensen 2017; Najjar et al. 2018). Furthermore, the exchange of organic matter within and between coastal habitats in tropical and subtropical regions varies depending on seascape configuration (Bouillon and Connolly 2009; Ricart et al. 2015a; Gullström et al. 2018) and is driven by abiotic conditions such as tidal forces (Slim et al. 1996) and biologically transferred energy through e.g. animal movement or trophic relays (Kneib 1997). Thus, the pathways for carbon transfers within the coastal seascape are many and highly diverse (Bouillon and Connolly 2009; Regnier et al. 2013; Fan et al. 2020), making it a challenge to assess and understand the fate of organic carbon across the land-sea continuum. The exchange of organic carbon between mangroves and seagrass meadows has been verified in a few studies (e.g. Slim et al. 1996; Bouillon and Connolly 2009), but how the strength of this link varies spatially across a coastal landscape influenced by land-use change is less understood.

Continuing degradation and loss of vegetated coastal ecosystems is a significant threat to natural blue carbon sinks globally (Pendleton et al. 2012). The extent of mangroves and seagrass meadows has been reduced by approximately one third during the past few decades as a consequence of human-driven stress (Waycott et al. 2009; Spalding et al. 2010; Mcleod et al. 2011). Such landscape transformation may have profound consequences for carbon dynamics (e.g. Pastick et al. 2017; Trevathan-Tackett et al. 2018). For management purposes, the protection of hotspot carbon-sink environments could contribute to a nature-based solution against increasing greenhouse gas emissions. However, in dynamic seascapes influenced by high-energy water movements, spatial heterogeneity and structurally complex habitats, it is intricate to determine the dynamics and fate of carbon, and hence how to enforce efficient management strategies. In addition, degradation of carbon-rich habitats in the coastal interface may lead to erosion of their sediment (Dahl et al. 2016a) and increased export to the adjacent environments (Duarte and KrauseJensen 2017). This could in turn alter the source-sink dynamics, exchange patterns and fate of organic matter, which may have ultimate implications for the habitats' carbon sink capacity (Bouillon and Connolly 2009).

Using a multiscale landscape ecology approach (Turner 1989; Wu and Hobbs 2002), we estimated patterns of variability of sedimentary organic carbon $\left(\mathrm{C}_{\text {org }}\right)$ storage in seagrass meadows with the overall aim to assess the influence of seascape configuration and land-use change (based on mangrove conversion) on the dynamics and fate of carbon within a coastal land-sea interface. The surveyed area, Tsimipaika Bay in northwest Madagascar, is a diverse mangroveseagrass coastal embayment, where extensive mangrove deforestation has occurred in localized areas of the bay. Based on a selection of fundamental landscape ecology-derived metrics, we predicted that the sedimentary $\mathrm{C}_{\text {org }}$ content $(\%)$, stocks $\left(\mathrm{g} \mathrm{m}^{-2}\right)$ and source composition (based on fractionation of $\delta^{13} \mathrm{C}$ ) in seagrass meadows may depend on (a) the spatial arrangement of habitat patches and distances to surrounding seascape features (mangrove forest, water channels, deep water, deforested area and seagrass meadow types), (b) patch heterogeneity of habitats (continuous vs. patchy areas), (c) within-patch attributes (seagrass structural complexity, sediment properties and bioturbating infauna), and (d) functional connectivity (supply and movement) from surrounding seascape features (including also degraded mangrove forest). We hypothesized that (1) broad landscape-scale metrics will have a strong influence on the dynamics and fate of carbon in seagrass sediments, and (2) deforestation of mangrove will 
increase levels and shift the composition of sedimentary $\mathrm{C}_{\text {org }}$ in recent sediments of adjacent seagrass meadows towards being more mangrove-generated.

\section{Material and methods}

Study site

The study was conducted in a mangrove-seagrass coastal seascape in the southeastern part of Tsimipaika Bay (previously referred to as Ambanja Bay; Jones et al. 2016) in northwestern Madagascar, encompassing an area of approximate $100 \mathrm{~km}^{2}\left(13^{\circ} 31^{\prime} 26.52^{\prime \prime} \mathrm{S}\right.$, $48^{\circ} 24^{\prime} 41.56^{\prime \prime} \mathrm{E}-13^{\circ} 28^{\prime} 8.94^{\prime \prime} \mathrm{S}, 48^{\circ} 29^{\prime} 48.91^{\prime \prime} \mathrm{E}$, Fig. 1), between September and December 2016. Seagrass meadows are distributed within a $7 \mathrm{~km}$ coastal shallow-water zone (Figs. 1c, 2). The dominating seagrass species in the bay is Enhalus acoroides (Ea), while mixed meadows composed of Cymodocea rotundatal serrulata and Thalassia hemprichii $(\mathrm{Cym} / \mathrm{Th})$ (primarily spread on the tidal flats) and meadows dominated by Thalassodendron ciliatum (Tc) (mainly growing further out towards the open ocean) are also common (Fig. 2). These three seagrass communities (i.e. $E a$,
Fig. 2 Illustrations of average proportion (\%) of organic carbon $\left(\mathrm{C}_{\mathrm{org}}\right)$ in the DW sediment $(\mathbf{a})$, sediment density $\left(\mathrm{g} \mathrm{DW} \mathrm{cm}^{-3}\right)$ (b), and accumulated organic carbon stocks $\left(\mathrm{g} \mathrm{C}_{\text {org }} \mathrm{m}^{-2}\right)(\mathbf{c})$ in the topmost $25 \mathrm{~cm}$ of sediment. Abbreviations: Unveg unvegetated area, $T c$ is the Thalassodendron ciliatum dominated habitat, Cym/Th mixed habitat dominated by Cymodocea rotundata/serrulata and Thalassia hemprichii, $\mathrm{Si}$ is the Syringodium isoetifolium dominated area, Ea is the Enhalus acoroides dominated habitat, Hal spp. is the Halodule spp. and Halophila spp. dominated area, mixed meadow area dominated by undefined seagrass species, deep ocean area with an average depth $>10 \mathrm{~m}$, mangrove intact forested mangrove area, mangrove disturbed deforested mangrove area, $S A V$ undefined submerged aquatic vegetation. The bar plots to the right represent mean $( \pm \mathrm{SE})$ proportion $(\%)$ of sedimentary (DW) organic carbon $\left(\mathrm{C}_{\mathrm{org}}\right)$ (top graph), sediment density (g DW $\mathrm{cm}^{-3}$ ) (mid graph), and accumulated sedimentary (DW) organic carbon $\left(\mathrm{g} \mathrm{C}_{\mathrm{org}} \mathrm{m}^{-2}\right.$ ) (bottom graph) in the topmost $25 \mathrm{~cm}$ of sediment in the different seagrass habitats, mangrove and unvegetated areas, respectively

Cym/Th and $T c$ ) constituted the focal habitats of this study due to their wide distribution (Gullström et al. 2002) and high potential as carbon sinks in the western Indian Ocean region (e.g. Githaiga et al. 2017; Gullström et al. 2018; Juma et al. 2020). The bay also contained vast scattered sandy areas with low densities of intermixed small-sized seagrasses belonging to the

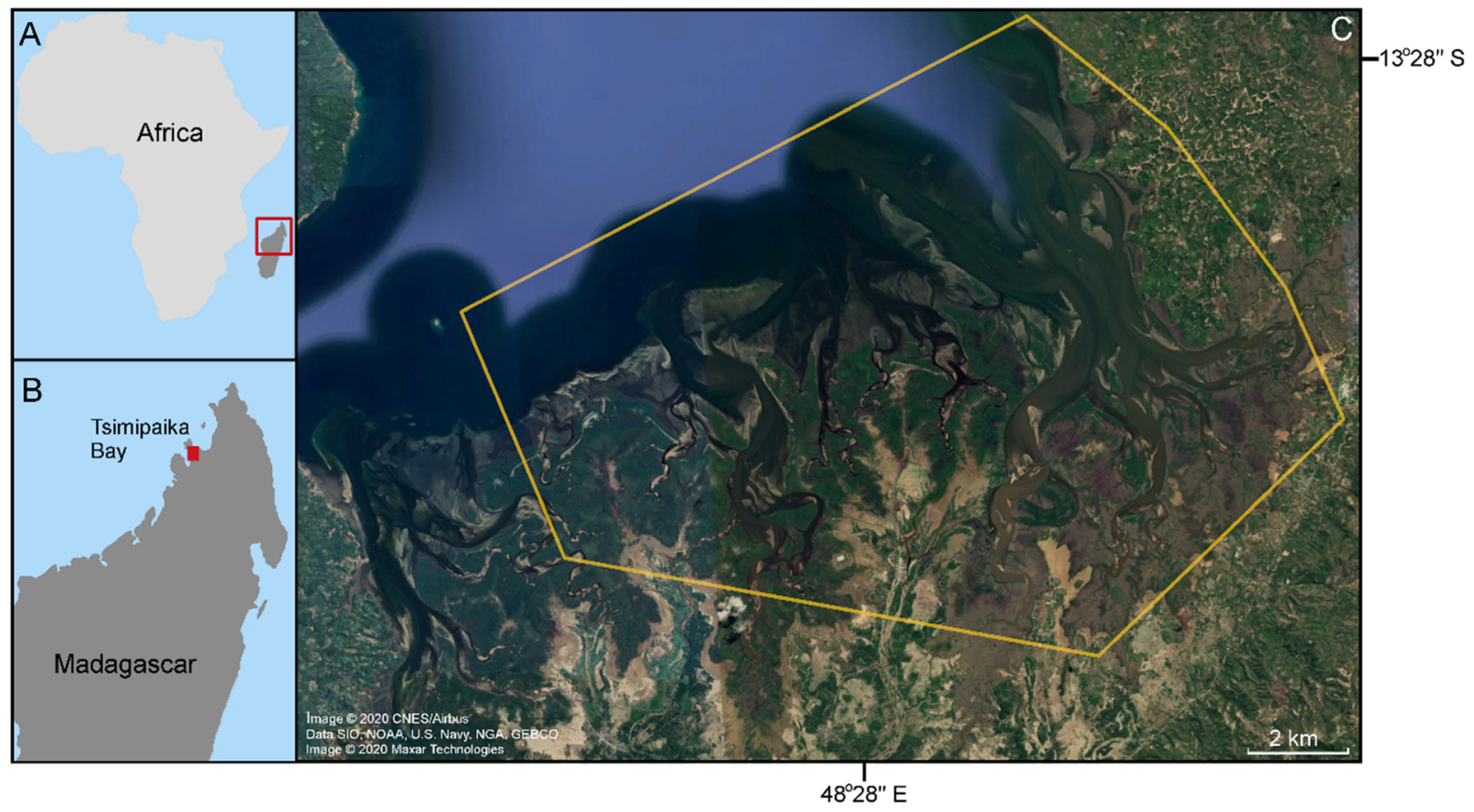

Fig. 1 Maps showing the location of the study area in Tsimipaika Bay (a, b previously referred to Ambanja Bay) in northwest Madagascar. The encircled area in the satellite image (c) visualizes the study area 

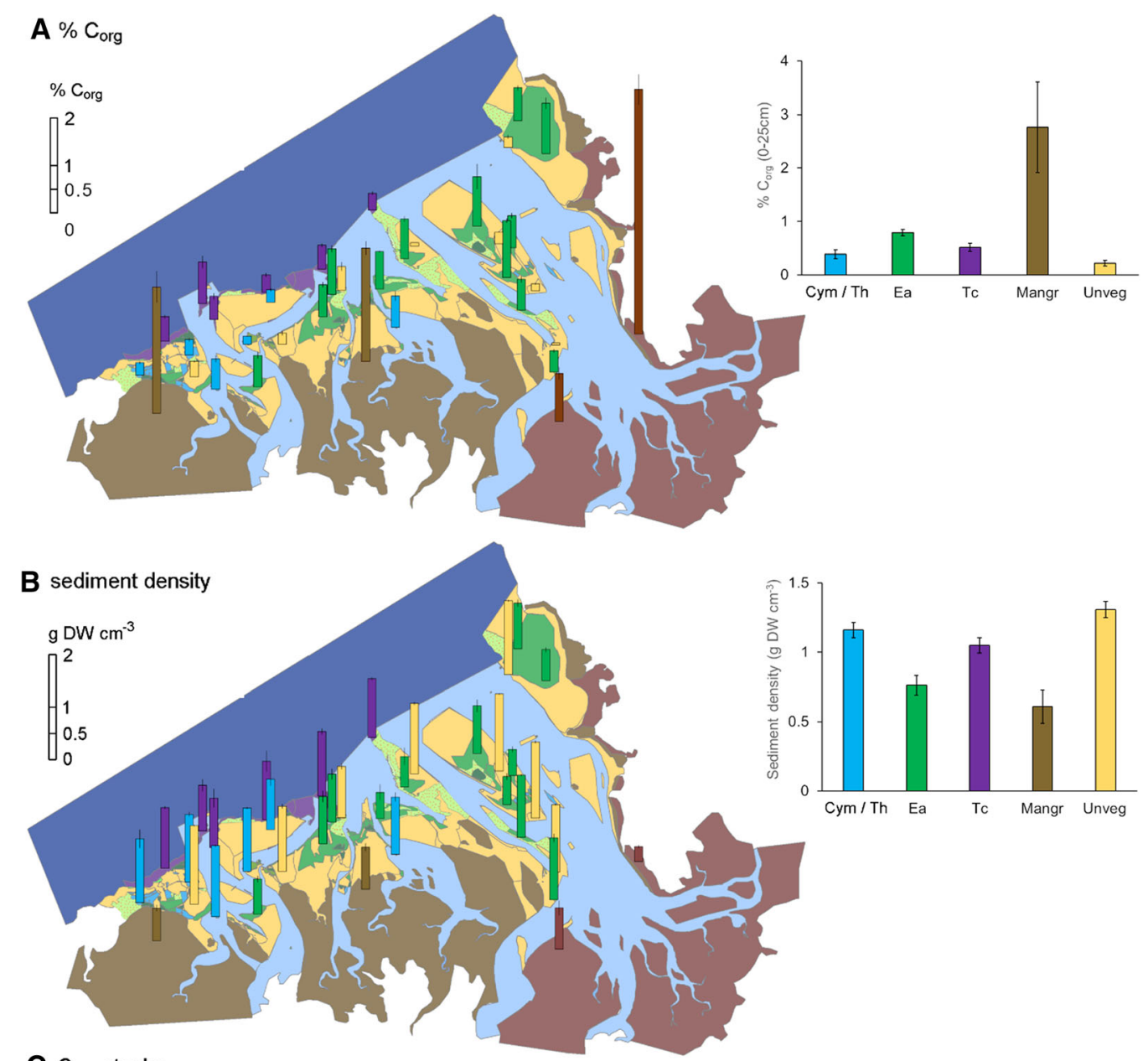

C Corg stocks

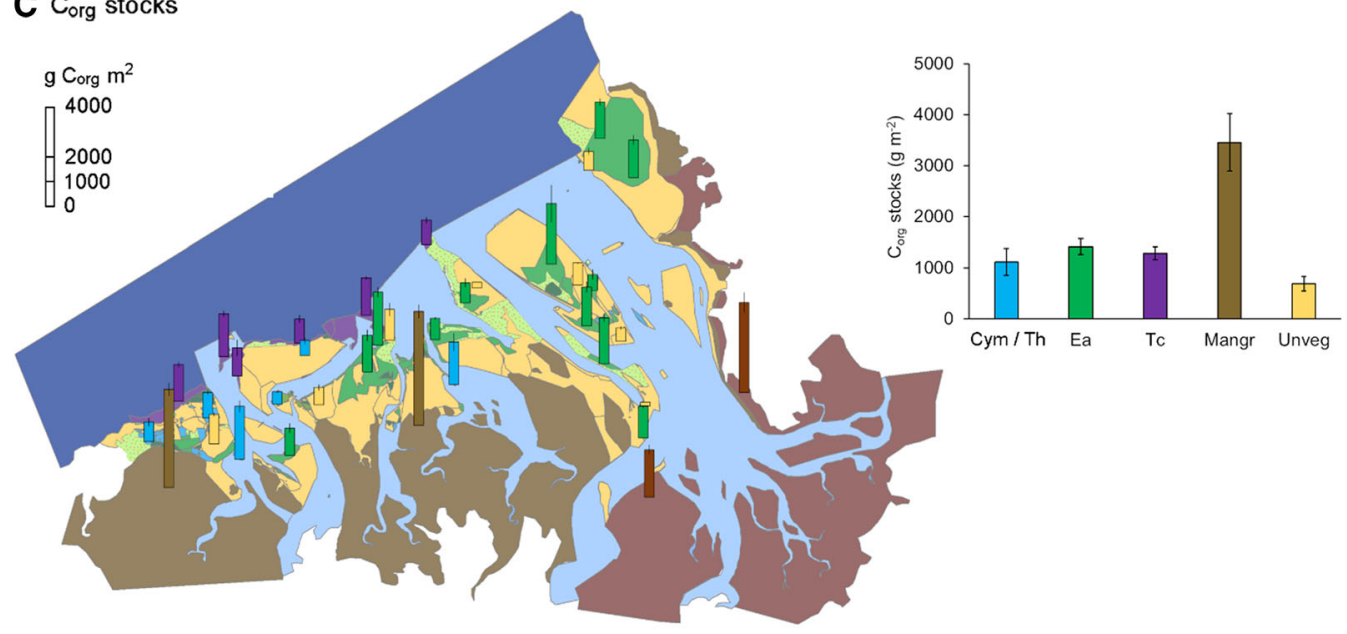

Habitats

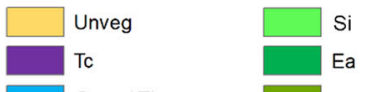

Cym / Th

\section{Ea}

Hal spp.

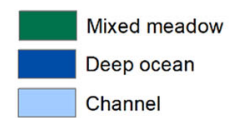

Channel
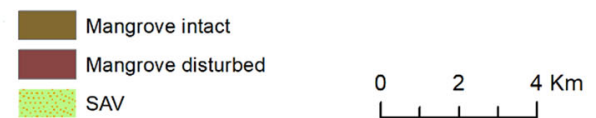
genera Halodule spp. and Halophila spp. (Fig. 2), which were not further investigated in the current study on the assumption that they in this high-current environment (being particularly short, thin and sparsely distributed mainly in the intertidal areas) are expected to have limited potential to capture large amounts of allochthonous organic material from other sources. However, it is known from e.g. Australian sites that Halophila ovalis contains considerably high carbon stocks, but the most probable reason for these high levels is that they there thrive in accumulation bottoms and that the seagrass shoots themselves contribute little to the carbon storage capacity (Lavery et al. 2013). Syringodium isoetifolium was also present, but only to a very minor extent (Fig. 2). The area is influenced by a semi-diurnal tidal regime with a mean spring tide of $3.8 \mathrm{~m}$ (McKenna and Allen 2005), generating both intertidal- and shallow-subtidal meadows. Hydrodynamic forces in the area are influenced by a complex network of rivers, mangrove creeks and coastal channels between the vegetated zones (Fig. 1). On the landward side of the seagrass meadows, the coastline is fringed by extensive mangrove forests, where the dominant species are Rhizophora mucronata, Ceriops tagal, Avicennia marina, Sonneratia alba and Bruguiera gymnorhiza (Jones et al. 2016; Arias-Ortiz et al. 2020). The Tsimipaika Bay together with Ambaro Bay (north of Tsimipaika Bay) comprises Madagascar's second most extensive mangrove area (Giri 2011), which since the 1990s has experienced extensive degradation for timber and charcoal extraction (Jones et al. 2016). The loss of mangroves in the entire Tsimipaika-Ambaro Bay complex has been estimated to about 1000 ha from 1990 to 2010 (Jones et al. 2014). Within the study area, substantial mangrove losses have occurred in the southeast, while the southwestern mangrove area is still relatively pristine (Jones et al. 2016, Fig. 2). The seascape area in closest vicinity to the deforested mangrove areas almost exclusively contained $E a$-dominated meadows, unvegetated areas and channels, while the major area adjacent to the intact mangroves comprised habitats with a larger variety of seagrass species. The terrestrial primary producers in the areas landward from the mangroves in Tsimipaika Bay consist of a mosaic of grass, bushes, cultivated forests and agricultural areas dominated by rice production (Jones et al. 2016).
Habitat mapping and landscape metrics for correlation analysis

Mapping of habitats was conducted along transect lines (stretching from the mangrove margin to the offshore seagrass meadow edges) that were placed about $50-100 \mathrm{~m}$ apart and perpendicular to the shoreline across the bay, either by walking in low tide or by boat using an aquascope in deeper water. Along each transect, the start and end of each habitat were marked (using a handheld GPS) and type of habitat (i.e. unvegetated area, specific seagrass species, channel or mangrove) noted. This information was added to the Google Earth software, where polygons were created using satellite imagery based on data from the field ground-truthing. The polygons were transferred to ArcMap 10.7 (ESRI, Redland), where areas of each habitat were calculated, while habitat areas of intact and deforested mangroves were adopted from Jones et al. (2016). Combining the two sets of habitat data, we produced a single complete habitat map in the ArcMap software. From the final habitat map, spatial metrics, including both seascape- and distance-based measures, were calculated. Seascapebased units of $1 \mathrm{~km}$ in diameter buffer zones were set around each seagrass sample site, and within each unit, size, proportion and diversity of the different habitats and patches were calculated (Table 1). Distances to the edges of intact- and deforested-mangrove areas, channels, coastal baseline (parallel to the coastline in an east-west direction across the embayment) and open ocean ( $>10 \mathrm{~m}$ depth) were measured from the center of each seascape unit (Table 1). The deforested mangrove distance metric was complemented by two additional measures of proximity to deforested mangroves (i.e. distances to midpoints of the eastern and central parts of the deforested area) to allow a spatially representative assessment of the associations to deforestation (Table 1).

Sampling of sediment

To assess the spatial dynamics of sedimentary $\mathrm{C}_{\mathrm{org}}$, sediment cores $(n=4)$ were collected (at least $10 \mathrm{~m}$ apart) from a total of 36 sites in selected habitats, including $E a$ - (n = 12 sites), $C y m / T h-(\mathrm{n}=6)$ and $T c$ $(n=6)$ meadows, mangroves $(n=4)$ and unvegetated areas $(n=8)$ across the bay (for locations, see Fig. 2) using push corers $(\varnothing=4.7 \mathrm{~cm}, \mathrm{~h}=60 \mathrm{~cm})$. The core 
Table 1 Metrics, and associated abbreviations, used as predictor variables in the partial least squares (PLS) regression analyses (Table 2) and PCA model (Fig. 4) for organic carbon $\left(\mathrm{C}_{\text {org }}\right)$ stocks

\begin{tabular}{|c|c|}
\hline Predictor metric & Abbreviation \\
\hline \multicolumn{2}{|l|}{ Distance metrics } \\
\hline Distance to mangrove & MangrDist \\
\hline Distance to deforested mangrove & DeforMangrDist \\
\hline Distance to deforested east area & DeforEastDist \\
\hline Distance to deforested center & DeforCentDist \\
\hline Distance to open ocean & OceanDist \\
\hline Distance to channel & ChanDist \\
\hline Distance to coastal baseline & CoastDist \\
\hline \multicolumn{2}{|l|}{ Seascape metrics } \\
\hline Patch number & PatchNum \\
\hline Patch richness & PatchRich \\
\hline Patch mean size & PatchSize \\
\hline Focal area size & seagrass FocalSeag \\
\hline Focal area size & Ea FocalEa \\
\hline Edge & Edge \\
\hline Simpson's diversity index & Simpson \\
\hline Seascape proportion $\mathrm{Ea}^{\mathrm{c}}$ & $\mathrm{Ea}$ \\
\hline Seascape proportion $\mathrm{Tc}^{\mathrm{a}}$ & $\mathrm{Tc}$ \\
\hline Seascape proportion Cym/ $\mathrm{Th}^{\mathrm{a}}$ & Cym/Th \\
\hline Seascape proportion unveg & Unveg \\
\hline Seascape proportion mangrove ${ }^{c}$ & Mangrove \\
\hline Seascape proportion channel & Channel \\
\hline \multicolumn{2}{|l|}{ Plant metrics } \\
\hline Seagrass canopy height & Canopy \\
\hline Seagrass shoot density & ShootDen \\
\hline Seagrass cover & SeagrCov \\
\hline Seagrass cover of dominant species ${ }^{\mathrm{a}}$ & SeagrCovDom \\
\hline Ea cover ${ }^{b}$ & EaCov \\
\hline \multicolumn{2}{|l|}{ Sediment metrics } \\
\hline Sediment density & SedDens \\
\hline Infaunal abundance & InfauAbun \\
\hline Infaunal biomass & InfauBiom \\
\hline
\end{tabular}

${ }^{a}$ Not included in the PLS-regression model for Enhalus acoroides $(E a)$-dominated seascapes (because of too few observations separated from zero)

${ }^{\mathrm{b}}$ In the PLS-regression model for $E a$-dominated seascapes, Ea was the dominating species

${ }^{\mathrm{c}}$ Not included in the PLS-regression model for Thalassodendron ciliatum (Tc)-dominated seascapes (because of too few observations separated from zero) sampling was performed by scientific SCUBA divers in submerged areas or by walking in low-tide water, depending on site location and contemporary tidal level (maximal depth: $\sim 6 \mathrm{~m}$ ). The sediment cores were extruded and sliced into six depth sections, including $0-2.5,2.5-5,5-12.5,12.5-25,25-37.5$ and $37.5-45 \mathrm{~cm}$. At least the sections down core to $25 \mathrm{~cm}$ depth could be retrieved in all cores and were later used in the carbon analysis. This is also a standard sediment depth used in several sediment carbon stock assessments (e.g. Lavery et al. 2013; Röhr et al. 2018). To assess any temporal dynamics and dating of the sediments, we collected nine long sediment cores using PVC tubes ( $\varnothing=6.2 \mathrm{~cm}, \mathrm{~h}=1.5 \mathrm{~m}$ ) in seven $E a$ meadows and two unvegetated sites. These long-core tubes were manually hammered into the sediments, extracted by hand and cut lengthwise. The sediments inside the long corers were sliced at 0.5 -cm-thick intervals throughout the first $20 \mathrm{~cm}$, and at 1-cm-thick intervals below this depth.

The bottom edge of the corers were sharpened to reduce sediment compression and to make it easier to shred the seagrass roots and rhizomes. Sediment compression was accounted for in all cores by measuring the distance from the top of the core to the sediment surface, inside and outside the corer after being inserted into the sediment (Glew et al. 2002). From this, the compression-correction factor (\%) was calculated for each core following Howard et al. (2014), for which the sediment volume of the slices in the core was adjusted. Average compressions were also calculated (short cores: $21 \pm 2.5 \%$, long cores: $20 \pm 5 \%$, mean $\pm \mathrm{SE}$ ).

Seagrass biometrics and infauna collection

To assess the influence of seagrass structural complexity and bioturbating infauna on sedimentary $\mathrm{C}_{\text {org }}$ variables (i.e. content, stocks and source composition), seagrass meadow plant biometrics and abundance and biomass of infauna were recorded randomly in the vicinity to each core sampled in the seagrass meadows. Mean seagrass canopy height (based on maximum shoot lengths, $n=20$ ) was measured with a measuring stick. Mean seagrass shoot density was estimated in $0.25 \times 0.25 \mathrm{~m}$ quadrats $(\mathrm{n}=5)$. Total cover (\%) of seagrass as well as cover of the dominant seagrass species were estimated in $0.5 \times 0.5 \mathrm{~m}$ squares $(n=10)$. Infauna was collected with a 
Table 2 Summary of partial least squares (PLS) regression models ranking the most important variables predicting $\mathrm{C}_{\text {org }}$ content (\%) in the topmost $25 \mathrm{~cm}$ of sediment for the seagrass seascapes in general and for community-specific seagrass seascapes.

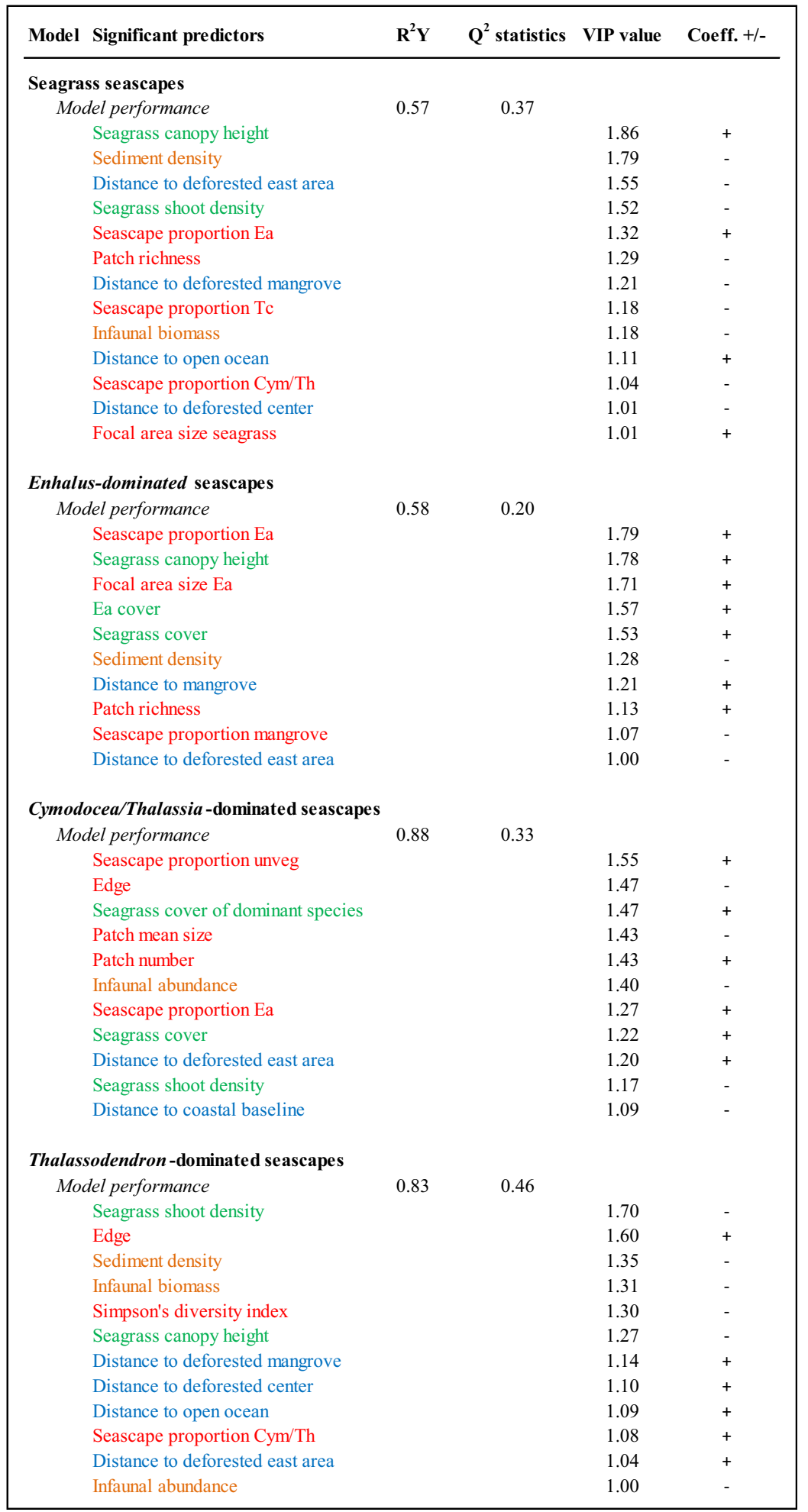


Table 2 continued

Colors refer to the different groups of predictor metrics, including distance metrics (blue), seascape metrics (red), sediment metrics (orange) and plant metric (green)

sediment push corer $(\varnothing=10 \mathrm{~cm})$ down to about $10 \mathrm{~cm}$ sediment depth and then sieved (1 mm mesh), counted (abundance) and weighted (wet weight biomass).

Sediment density and carbon analysis

Sediment slices from the cores were weighed wet, homogenized (by stirring) and a subsample of $60 \mathrm{~mL}$ (short cores) or the whole section (long cores) from each depth was dried at $60{ }^{\circ} \mathrm{C}$ for approximately $48 \mathrm{~h}$ until constant weight. For each sediment slice, dry bulk density ( $\mathrm{g} \mathrm{DW} \mathrm{cm} \mathrm{cm}^{-3}$; hereafter referred to as sediment density) was calculated and adjusted to the compression corrected volume for each core slice. Sediment samples were sieved $(1 \mathrm{~mm})$ to exclude large living plant material and shells before they were ground to a fine powder using a mixing mill (Retch 400) for subsequent carbon analysis.

The carbon content, i.e. \% C of the DW sediment from both short- and long-cores, was analyzed using a carbon-nitrogen elemental analyzer (Flash 2000, Thermo Fisher Scientific, Waltham, MA, United States, precision error $<0.02 \%$ for carbon). Each sediment sample was divided into two subsamples for analysis of the total carbon $\left(\mathrm{C}_{\text {tot }}\right)$ and $\mathrm{C}_{\text {org }}$ contents (\%). Prior to $\mathrm{C}_{\mathrm{org}}$ analysis, the subsamples were treated with $1 \mathrm{M} \mathrm{HCl}$ (by direct pipetting) to remove inorganic carbon and dried for about $24 \mathrm{~h}$. The inorganic carbon content was then determined from the difference between the $\mathrm{C}_{\text {tot }}$ and $\mathrm{C}_{\text {org }}$ contents. The weighted average of $\% \mathrm{C}_{\text {org }}$ content down to each specific depth in the sediment was determined. Accumulated areal organic carbon stocks $\left(\mathrm{g} \mathrm{C}_{\mathrm{org}} \mathrm{m}^{-2}\right)$ were estimated by integrating the $\mathrm{C}_{\text {org }}$ density (i.e. $\mathrm{C}_{\text {org }}$ multiplied by the compression-corrected sediment density) with depth above the upper 25 and $100 \mathrm{~cm}$ in the short and long cores, respectively.

\section{Stable isotope analysis}

Bulk stable isotope signals of carbon $\left(\delta^{13} \mathrm{C}\right)$ and nitrogen $\left(\delta^{15} \mathrm{~N}\right)$ were analyzed (at UC Davis Stable Isotope Facility, CA, USA) in sediment from
16 sites, including meadows dominated by either $E a$ $(\mathrm{n}=8), T c(\mathrm{n}=3)$ or $C y m / T h(\mathrm{n}=2)$ as well as unvegetated sites $(\mathrm{n}=3)$ at different locations within the bay. In total, 48 cores (three from each site) were analyzed for stable isotope signals. The measures were conducted in each sediment depth interval of each core and were thereafter used to calculate the weighted average for each core. Material for potential $\mathrm{C}_{\text {org }}$ sources ( $\mathrm{n}=4$ from each source) was collected, including samples of above- and below-ground seagrass biomass (from seagrass meadows dominated by the different species), mangrove- and terrestrial-plant material and suspended particulate organic matter (SPOM) from offshore waters. SPOM was collected by filtering $1.5 \mathrm{~L}$ of water onto pre-combusted $\mathrm{GF} / \mathrm{F}-$ filters and the plant material was washed, cleaned from epiphytes, dried and ground before analysis. To remove inorganic carbon prior to analysis, the sediment, seagrass biomass and SPOM were treated with low concentrated acid $(1 \mathrm{M} \mathrm{HCl})$ to minimize any $\delta^{15} \mathrm{~N}$ fractionation according to recommendations in Kennedy et al. (2005). The isotope signals were analyzed with a micro cube elemental analyzer (Elementar Analysensysteme GmbH, Hanau, Germany) interfaced with an isotope ratio mass spectrometer (EA-IRMS). The samples were interspersed with four known laboratory references (bouvine liver, glutamatic acid, enriched alanine and nylon 6), which are calibrated against international reference materials (Sharp 2005), and the temporary isotope ratio generated is thus relative to the reference gas peak analyzed with each sample. These temporary ratios are consequently corrected for the entire batch based on the known laboratory references, generating the final ratios. The samples' isotope ratios were expressed as $\delta$ values in parts per thousand (\%o) relative to VPDB (Vienna Pee Dee Belemnite) for carbon and air for nitrogen (Sharp 2005). The long term standard deviation for the EA-IRMS is $\pm 0.2 \%$ for $13 \mathrm{C}$ and \pm 0.3 $\%$ for $15 \mathrm{~N}$.

Specific ${ }^{210} \mathrm{~Pb}$ activities were measured in the upper $40 \mathrm{~cm}$ of six of the long cores from $E a$-dominated meadows to assess potential changes in sediment accumulation rates and dynamics with time (i.e. last 
century to decades). For details of methods and results, see supplementary material $\left({ }^{210} \mathrm{~Pb}\right.$ analysis for sediment dating”). Total ${ }^{210} \mathrm{~Pb}$ and ${ }^{226} \mathrm{Ra}$ specific activities (derived by alpha- and gamma-spectrometry, respectively) were within error of one another from the surface to the bottom of the analyzed cores, confirming agreement between alpha and gamma methods but resulting in negligible excess ${ }^{210} \mathrm{~Pb}$ concentrations, and thereby non-datable sediment profiles (Arias-Ortiz et al. 2018).

\section{Data analysis}

To elucidate the relative importance of the different predictors (i.e. distance-, seascape-, plant-, and sediment-metrics; Table 1) for the $\mathrm{C}_{\text {org }}$ content (\%) in the topmost $25 \mathrm{~cm}$ of the sediment in the studied seascapes as well as for $\%$ source of origin of $\mathrm{C}_{\mathrm{org}}$ (evaluating distance metrics only), the data were analyzed with projection to latent structures models by means of partial least squares (PLS) regression analysis (Wold et al. 2001) on $\log _{10}(\mathrm{x}+1)$-transformed data using the software SIMCA-P + 15.0.2 (UMETRICS). PLS analyses were conducted on data including all seagrass seascapes as well as on data from seascapes of each seagrass community (i.e. $E a$, $C y m / T h$ and $T c$ ) separately. Principal component analysis (PCA) was performed in SIMCA$\mathrm{P}+$ 15.0.2 (UMETRICS) to explore and visualize (in a biplot) the potential associations between the explanatory metrics, the sedimentary $\mathrm{C}_{\text {org }}$ content and the different seagrass sampling sites.

Variation in the sedimentary $\mathrm{C}_{\text {org }}$ content $(\%)$, sediment density and accumulated $\mathrm{C}_{\text {org }}$ stocks $\left(\mathrm{g} \mathrm{m}^{-2}\right)$ among the different seagrass habitats (i.e. $\mathrm{Ea}, \mathrm{Cym} / \mathrm{Th}$ and $T c$ ) and unvegetated areas was tested with oneway ANOVAs. The mangrove samples were excluded in the statistical comparison due to the limited sample size (since they were not in focus in the current study). A posteriori multiple comparisons were conducted using Tukey's HSD test. Prior to all analyses, data were tested to meet the assumption of homogeneity of variances (Levene 1960). To be able to compare the means in $\mathrm{C}_{\text {org }}$ among habitat types, we assessed if the sampled sites were randomly selected (not spatially autocorrelated) using a spatial autocorrelation model (Morans I) on the $\% \mathrm{C}_{\text {org }}$ data (0-25 cm depth) for the 36 study sites in ArcGIS v. 10.7 (Supplementary Fig. S2). Variation in $\mathrm{C}_{\text {org }}$ content, sediment density and accumulated $\mathrm{C}_{\text {org }}$ stocks in the long sediment cores were compared between $E a$-dominated meadows and unvegetated sites using the non-parametric Kruskal-Wallis test (since with the $\log _{10}(\mathrm{x}+1)$ transformation, homogeneity of variance was not achieved). All univariate statistics were performed using Statistica v. 13. The sources contributing to the sedimentary $\mathrm{C}_{\text {org }}$ (based on the stable isotope signals) were analyzed with the Stable Isotope Analysis (SIAR) package in R (v. 3.5.3). The model was based on original concentrations of carbon and nitrogen and the discrimination factors used were $3 \%$ for $\delta^{15} \mathrm{~N}$ and $1 \%$ for $\delta^{13} \mathrm{C}$ to cover the ranges of output signals in seagrass ecosystems as summarized by Lepoint et al. (2004). As the mangrove and terrestrial material had overlapping $\delta^{13} \mathrm{C}$ signatures (Lamb et al. 2006), these two sources were pooled prior to analysis, and the specific sources used in the final analysis were seagrass plants, mangrove/terrestrial material and SPOM (see Supplementary Fig. S1 showing a biplot of the $\delta^{15} \mathrm{~N}$ and $\delta^{13} \mathrm{C}$ signals of the sources used in the mixing model).

\section{Results}

Sediment carbon content, bulk density and carbon stocks

The sedimentary $\mathrm{C}_{\text {org }}$ content (\%), sediment density $\left(\mathrm{g} \mathrm{DW} \mathrm{cm}^{-3}\right.$ ) and accumulated $\mathrm{C}_{\text {org }}$ stocks $\left(\mathrm{g} \mathrm{C}_{\text {org }}\right.$ $\mathrm{m}^{-2}$ ) did clearly vary in the seagrass surface sediments (0-25 cm depth) across sites in the embayment (ranges: $0.16-1.18 \% \mathrm{C}_{\text {org }}, 0.49-1.32 \mathrm{~g} \mathrm{DW} \mathrm{cm}^{-3}$, 496-2383 $\mathrm{g} \mathrm{C}_{\text {org }} \mathrm{m}^{-2}$, respectively, Fig. 2). There were also significant differences at habitat level (comparing Ea, Cym/Th, Tc and unvegetated areas) (ANOVA; $\mathrm{C}_{\text {org }}$ content: $F_{3,28}=15.6, \mathrm{p}<0.001$; Sediment density: $F_{3,28}=14.2, \quad \mathrm{p}<0.001 ; \quad \mathrm{C}_{\text {org }}$ stocks: $F_{3,28}=3.5, \mathrm{p}<0.05$; Fig. 2). Ea sediments contained higher $\mathrm{C}_{\text {org }}$ content (Tukey's HSD, $\mathrm{p}<0.01)$ while lower sediment density levels (Tukey's HSD test, $\mathrm{p}<0.05$ ) compared to the other seagrass habitats and unvegetated areas. For the $\mathrm{C}_{\text {org }}$ stocks, there were no significant differences among the seagrass communities. Unvegetated sediment contained lower $\mathrm{C}_{\text {org }}$ content than $E a$ - and $T c$-sediments (Tukey's HSD, $\mathrm{p}<0.01$ ), but did not differ from Cym/Th sediments. The sedimentary $\mathrm{C}_{\text {org }}$ contents and 

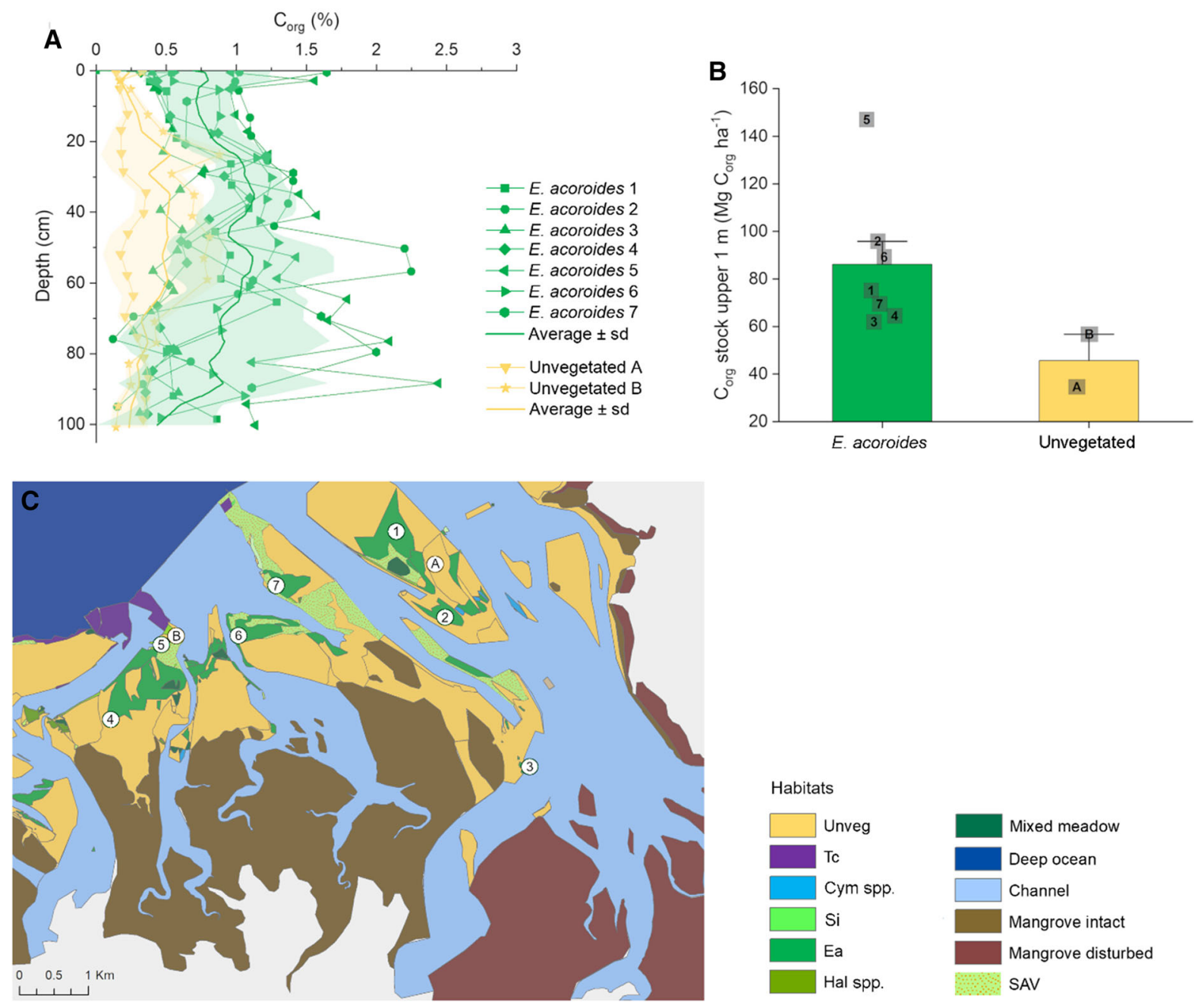

Fig. 3 Organic carbon $\left(\mathrm{C}_{\mathrm{org}}\right)$ content $(\%)$ profiles in the upper meter of sediments in Enhalus acoroides (green) and unvegetated (yellow) areas (a), top meter $\mathrm{C}_{\text {org }}$ stocks ( $\mathrm{Mg} \mathrm{C}_{\text {org }}$ ha $^{-1}$,

stocks in the fringing mangrove habitats varied substantially, while the mean level was manifold higher than those in the seagrass- and unvegetatedhabitats (Fig. 2a, c). The mean content of inorganic carbon in the sediment ranged from $\sim 12 \%$ in mangroves to $\sim 40 \%$ in the habitats dominated by $E a$ or $C y m / T h$ and $\sim 60 \%$ in $T c$-dominated meadows and unvegetated areas.

Considering the upper meter of sediment (from long cores; Fig. 3), $\mathrm{C}_{\text {org }}$ content varied among the $E a$ sites and downcore the sediment of individual cores (Fig. 3a). However, on average the $\mathrm{C}_{\text {org }}$ content was relatively constant with depth (Fig. 3a). The average mean $\pm \mathrm{SE}$ ) including the measures from each site (b) and the locations where the long cores were samples in Tsimipaika Bay (c)

$\mathrm{C}_{\text {org }}$ content and stocks in the upper meter of $E a$ sediments (content: $0.89 \pm 0.04 \%$, Fig. 3a; stocks: $86 \pm 11 \mathrm{Mg} \mathrm{C} \mathrm{ha}{ }^{-1}$, mean $\pm \mathrm{SE}$, Fig. 3b) were significantly higher than in unvegetated sites (content: $0.35 \pm 0.03 \%$, Fig. 3a; stocks: $46 \pm 11 \mathrm{Mg} \mathrm{C}^{-1}$ ) (Kruskal-Wallis, $\mathrm{p}<0.01$ ).

Total ${ }^{210} \mathrm{~Pb}$ specific activities in the upper $40 \mathrm{~cm}$ of $\mathrm{Ea}$ sediment were constant with depth (range: $19.1 \pm 1.2$ to $85.5 \pm 4.5, \mathrm{~Bq} \mathrm{~kg}^{-1}$ ) and agreed with ${ }^{226} \mathrm{Ra}$ specific activities (range: $29 \pm 2$ to $106 \pm 8$, $\mathrm{Bq} \mathrm{kg}^{-1}$ ) (Supplementary Fig. S2). The lack of excess ${ }^{210} \mathrm{~Pb}$ in the six long cores of $E a$ sediment suggests negligible recent net accumulation of sediment. 
Influence of scale-dependent metrics on sediment $\mathrm{C}_{\text {org }}$ content

\section{Overall PLS-modelling performance}

The PLS regression models showed that all metric categories (i.e. distance-, seascape-, plant- and sediment-metrics) were represented among the foremost predictors of sedimentary $\mathrm{C}_{\text {org }}$ content $(\%)$ in the topmost $25 \mathrm{~cm}$ of sediment, both when including all seagrass seascapes and when specifically focusing on seascapes of each of the three seagrass communities (i.e. Ea, Cym/Th and Tc; Table 2). The $\mathrm{Q}_{2}$-statistics for the different seagrass seascape models showed a crossvalidated variance ranging from 20 to $46 \%$ (i.e. higher than the defined significance limit of 5\%) and hence the models displayed good predictability (Table 2). The cumulative portion of all predictors combined $\left(\mathrm{R}_{\mathrm{y}}^{2}\right)$ explained $57-88 \%$ of the variance of the $\mathrm{C}_{\mathrm{org}}$ content, which shows that the models displayed high level of determination (Table 2). In the PLS models, between 10 and 13 of the 27 predictors tested had a variable of importance (VIP) value over 1 and thus contributed significantly to the respective model (for ranking order, see Table 2).

\section{Influence of plant- and sediment-metrics}

Seagrass structural complexity measures in terms of canopy height (positively correlated) and shoot density (negatively correlated) were among the most important predictors explaining the sedimentary $\mathrm{C}_{\text {org }}$ content in the models for all seagrass seascapes and Ea-dominated seascapes (Table 2). In contrast to these two models, canopy height was negatively correlated to $\mathrm{C}_{\text {org }}$ in $T c$-dominated sediment (Table 2). Among the plant metrics, the various seagrass cover predictors also contributed to the performance of some models, although to a lesser degree than canopy height and shoot density (Table 2). Besides the importance of plant structure measures as within-meadow predictors of $\mathrm{C}_{\mathrm{org}}$, sediment metrics in terms of sediment density (most important), infaunal abundance and infaunal biomass (all negatively correlated to sedimentary $\mathrm{C}_{\text {org }}$ content) also contributed (in various ways depending on seascape model) to the performance of the different models (Table 2).

\section{Influence of distance- and seascape-metrics}

Spatial pattern analysis based on distance- and seascape-metrics demonstrated significant relationships between several of the examined predictors and the level of $\mathrm{C}_{\text {org }}$ content in seagrass sediment (Table 2). A variety of seascape metrics measuring seascape proportion of different habitats, focal area size and patch heterogeneity (i.e. number, richness, mean size and edge of patches) were related to sedimentary $\mathrm{C}_{\text {org }}$ content (Table 2). Seascape proportion of $E a$ had a strong positive influence on sedimentary $\mathrm{C}_{\text {org }}$ levels in seagrass seascapes in general and in Ea-dominated seascapes (Table 2). Seascape proportion of the two other seagrass communities (i.e. Cym/Th and $T c$ ) and focal area size of seagrass also seem to be important for the sedimentary $\mathrm{C}_{\text {org }}$ content, although the strength and nature of the relationships showed communityspecific variation (Table 2). For instance, opposite to the positive influence of seascape proportion of $E a$ on sedimentary $\mathrm{C}_{\text {org }}$, seagrass seascapes in general showed a negative relationship between seascape proportion of $C y m / T h$ or $T c$ and $\mathrm{C}_{\text {org }}$ content in the sediment (Table 2). The significant patch-related seascape metrics showed mixed influences on sedimentary $\mathrm{C}_{\text {org }}$ content (Table 2). In particular, edge was a strong predictor, with an opposite influence on $\mathrm{C}_{\text {org }}$ content in sediment of Cym/Th-dominated seascapes (negative relationship) and seascapes dominated by $T c$ (positive relationship).

The distance metrics showed community-specific relationships to sedimentary $\mathrm{C}_{\text {org }}$ content in seagrass meadows of the bay (Table 2). For instance, distance to deforested mangrove (including the three distance metrics to deforestation, Table 1) were negatively related to $\mathrm{C}_{\text {org }}$ content in general seagrass seascapes and those dominated by $E a$, while positively in $C y m /$ $T h$-dominated seascapes and those dominated by $T c$ (Table 2).

\section{Multivariate PCA model}

The PCA-biplot visualized clear community-specific clusters grouping the different seascapes in relation to the scale-dependent predictors (i.e. distance-, seascape-, plant- and sediment-metrics) and all variables of sedimentary $\mathrm{C}_{\text {org }}$ content (Fig. 4). Generally, sedimentary $\mathrm{C}_{\text {org }}$ content was positively coupled to the model observation metrics of the Ea-dominated 


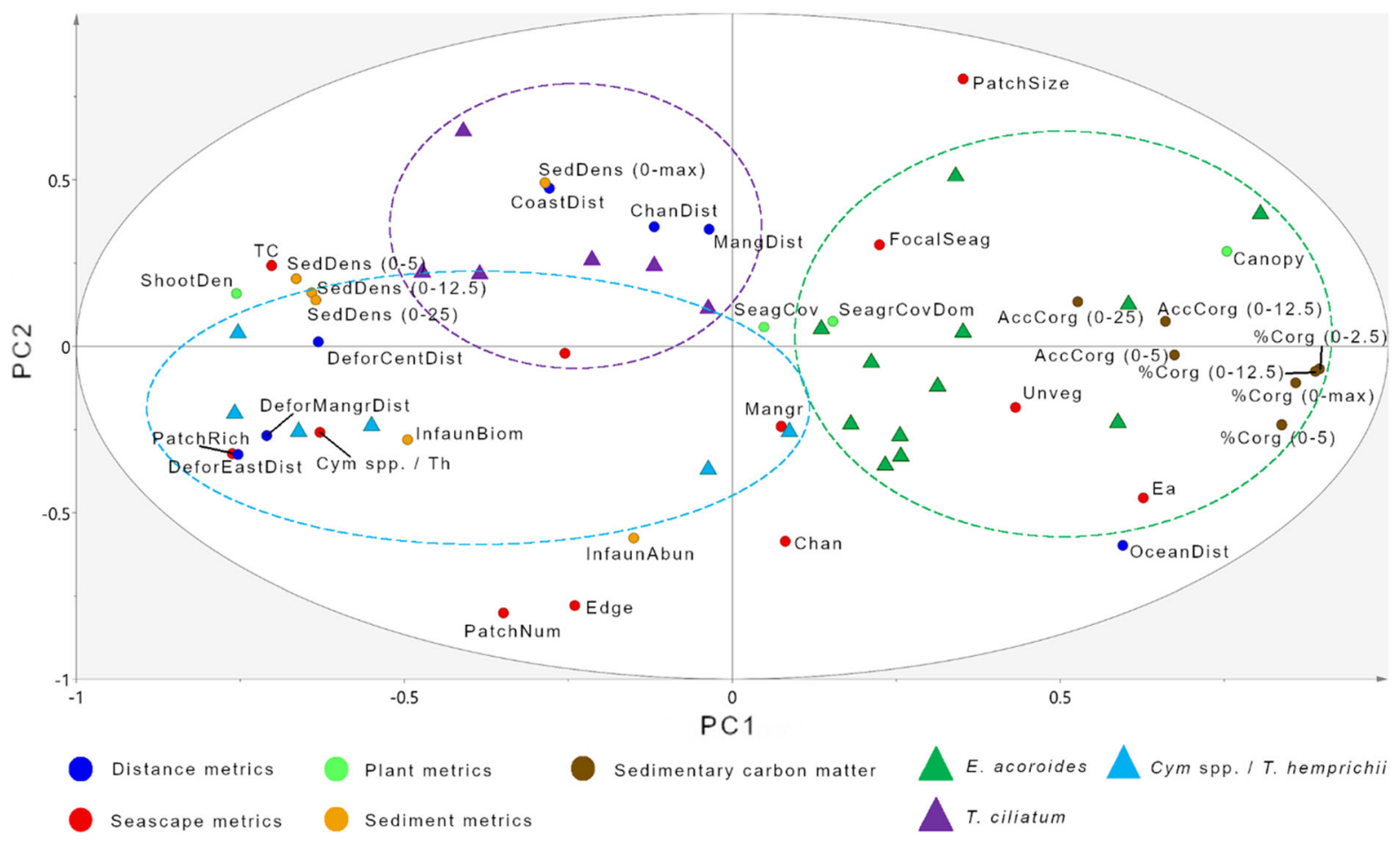

Fig. 4 Principal component analysis (PCA) biplot displaying correlative assessments of scale-dependent predictors (distance, seascape-, plant- and sediment-metrics), sedimentary $\mathrm{C}_{\text {org }}$ content at different depth sections and the model observation metrics of each seagrass seascape represented by Enhalus

seascapes, while the seascapes dominated by $C y m / T h$ or $T c$ showed opposite patterns, with negative relationships to the $\mathrm{C}_{\text {org }}$ content (Fig. 4). The communityspecific clusters show that seagrass canopy height was closely and positively related to the Ea-dominated seascapes, while seagrass shoot density was clearly positively related to seascapes dominated by $C y m / T h$ or Tc (Fig. 4). Particular distance metrics of importance (for PC1) were proximity to deforested mangrove and distance to open ocean (Fig. 4). Closer proximity to deforested mangrove and larger distance to open ocean seemed to influence the model observation metrics of the $E a$-dominated seascapes, while larger distances from the deforested mangrove seemed to particularly influence the metrics of the Cym/Thdominated sites (Fig. 4). Sediment depth represented by the different depth sections of organic carbon content $\left(\% \mathrm{C}_{\text {org }}\right)$ and accumulated stocks $\left(\operatorname{Acc} \mathrm{C}_{\text {org }}\right)$ were highly clustered and therefore had minor influence on the model performance (Fig. 4). acoroides, Cymodocea spp./Thalassia hemprichii and Thalassodendron ciliatum in Tsimipaika Bay. For abbreviations, see Table 1. PC1: $\mathrm{R}^{2}{ }_{\mathrm{x}}=0.317, \mathrm{PC} 2: \mathrm{R}^{2}{ }_{\mathrm{x}}=0.133, \mathrm{Q}_{\text {cum }}=0.117$ (i.e. $>$ significance limit of 0.07 )

Source and fate of organic material

The isotopic signals did not vary among the different seascape habitats (i.e. Ea, Cym/Th, Tc and Unveg) (Fig. 5a), while the landscape context showed an influence (Fig. 5b). Overall closeness to mangrove (deforested areas in particular) generated a strong mangrove/terrestrial organic material signal, while the seagrass contribution of $\mathrm{C}_{\text {org }}$ in the sediment seemed to be larger towards the open ocean. A significant PLS regression model $\left(\mathrm{Q}_{2}\right.$-statistics $\left.=24 \%, \mathrm{R}_{\mathrm{y}}^{2}=53 \%\right)$ between distance metrics and organic material originating from the mangrove/terrestrial source in the sediment showed that distance to open ocean (ranked 1 , positively correlated) and distance to channel (ranked 2, negatively correlated) were significantly (VIP values $>1$ ) related to the variation in contribution of mangrove/terrestrial organic material to the sedimentary $\mathrm{C}_{\text {org }}$ pool (Fig. $5 \mathrm{c}$ ). 

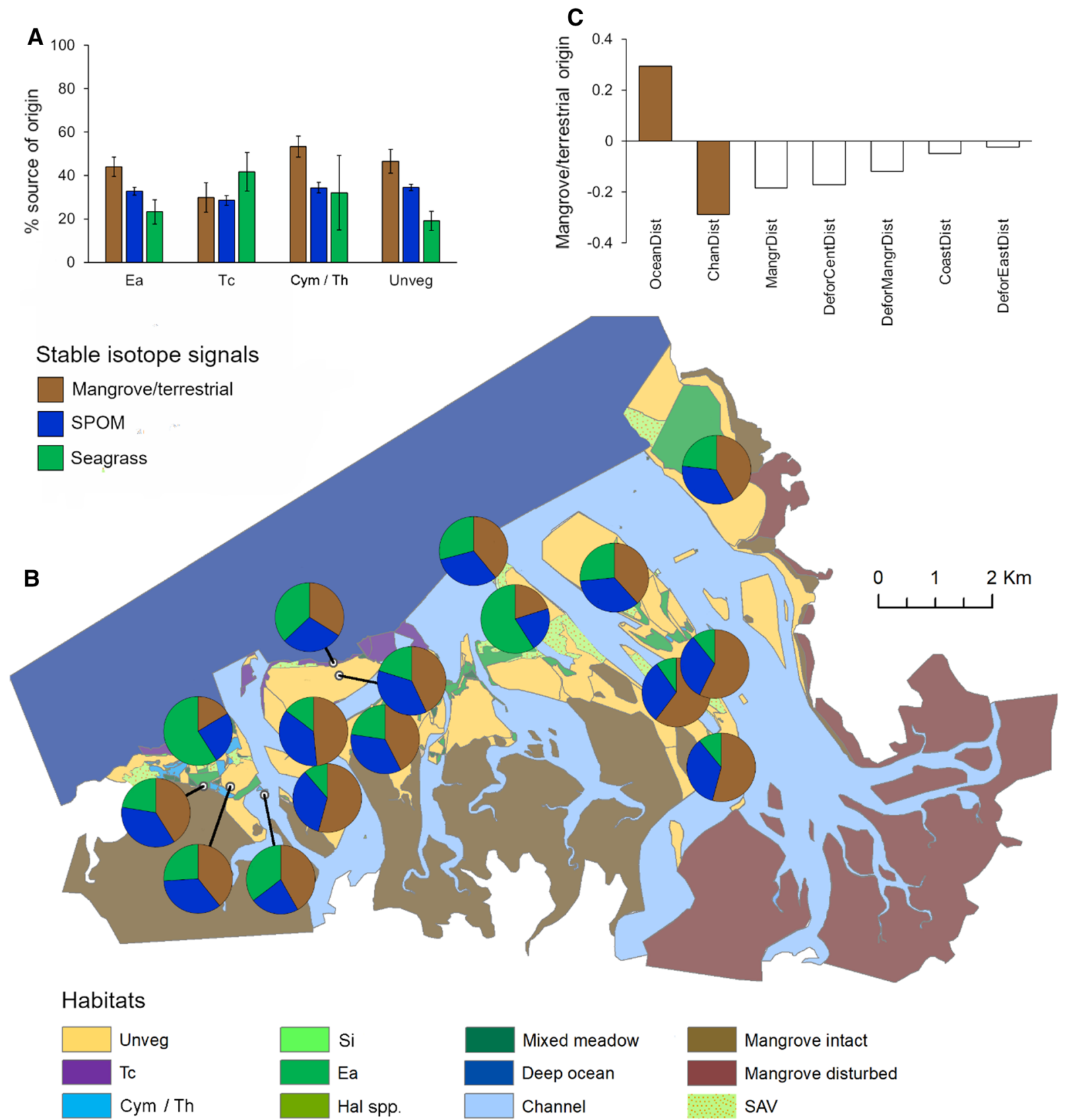

Fig. 5 Mean of relative contributions in percent $( \pm \mathrm{SE})$ of organic material originating from mangrove/terrestrial environments, suspended particulate organic matter (SPOM) or seagrass in the different seagrass-dominated seascapes (a). Relative contributions (\%) of organic material from seagrass plants and imported $\mathrm{C}_{\mathrm{org}}$, from mangrove/terrestrial vegetation and SPOM present in the bulk sediment of seagrass meadows determined by isotope signals of carbon $\left(\delta^{13} \mathrm{C}\right)$ and nitrogen $\left(\delta^{15} \mathrm{~N}\right)(\mathbf{b})$. Summary of partial least squares (PLS) regression model ranking in a descending scale from left to right the most important distance metrics predicting the percent organic material originating from mangrove or other terrestrial source in the seagrass seascapes. Numbers above/below bars present variable influence on the projection (VIP) values. Brown bars represent predictor metrics with VIP values above 1, i.e. metrics that contribute significantly to model performance (c). For habitat abbreviations, see legend of Fig. 2 


\section{Discussion}

We found that seascape configuration and mangrove deforestation had a strong influence on $\mathrm{C}_{\text {org }}$ content and source composition in coastal sediments of the studied land-sea continuum. Our findings suggest that the carbon sink capacity of seagrass meadows is driven by factors operating at multiple spatial scales (from $\mathrm{m}$ to $10 \mathrm{~s} \mathrm{~km}$ ). Landscape configuration (spatial arrangement of habitat patches and geographic distances to surrounding seascape features), patch heterogeneity (degree of continuity) and within-patch attributes (seagrass structural complexity and sediment properties) were all metrics of importance for the models' performance. The outcome revealed a strong land-to-sea gradient, possibly forced by hydrodynamically driven exchange of organic matter across the bay landscape which may be enhanced by recent (last decades) escalation in export of organic carbon from deforested mangroves, with higher $\mathrm{C}_{\text {org }}$ levels and a clear mangrove/terrestial signal found in surface sediment $(0-25 \mathrm{~cm})$ of seagrass seascapes located closer to deforested mangrove area. The substantial input of allochthonous carbon derived from adjacent habitats to the seagrass meadows emphasizes the importance of cross-habitat connectivity within the coastal seascape. Lateral transfer of organic carbon from mangrove areas (cleared and intact) and increased carbon content in the surface sediment may, however, not necessarily lead to accumulation of carbon stocks, as we observed no recent net accumulation of sediments (where the long cores were collected). This suggests well mixed sediments, which commonly occur in high-energy environments (AriasOrtiz et al. 2018). Of particular importance for conservation of blue carbon sinks may be this study confirms that seascapes comprising large continuous seagrass meadows had higher $\mathrm{C}_{\text {org }}$ levels in comparison to more diverse or patchy seascapes.

Relative importance of landscape configuration, patch heterogeneity and within-patch attributes

A multitude of scale-dependent metrics were important predictors influencing spatial patterns and variability of $\mathrm{C}_{\text {org }}$ content in seagrass sediment. While spatial heterogeneity of landscapes is fundamentally scale-dependent (Wu 2004), determining the relative importance of drivers at multiple spatial scales can be very challenging to unravel, especially given the broad range of process-oriented patterns in nature. Our study showed that the sedimentary carbon content varied spatially from low to moderate levels across seascapes in the embayment. The $\mathrm{C}_{\text {org }}$ levels were lower than the global mean of $\sim 2 \%$ (Fourqurean et al. 2012), but comparable to other tropical and subtropical seagrass areas (e.g. Fourqurean et al. 2012; Lavery et al. 2013; Phang et al. 2015), including studies from the western Indian Ocean (Dahl et al. 2016a; Githaiga et al. 2017; Belshe et al. 2018; Gullström et al. 2018, 2021). The top meter of sedimentary $\mathrm{C}_{\mathrm{org}}$ stocks (i.e. from the $E a$ dominated meadows) is comparable to estimates from other subtropical regions $\left(72-90 \mathrm{Mg} \mathrm{C}\right.$ org ha ${ }^{-1}$; Miyajima et al. 2015; Serrano et al. 2019) and two times higher than $\mathrm{C}_{\text {org }}$ stocks observed in unvegetated sediments.

The analysis of spatial attributes demonstrated that landscape configuration and position within the coastal landscape strongly influence sedimentary $\mathrm{C}_{\text {org }}$ in seagrass meadows. In accordance, Ricart et al. (2020) found that sedimentary $\mathrm{C}_{\text {org }}$ stocks were related to landscape configuration (based on seagrass meadow type) in a coastal estuary. In general, a higher seascape proportion of $E a$ positively influenced the sedimentary $\mathrm{C}_{\text {org }}$ content. Thus, the larger the area covered with the focal seagrass, the more $\mathrm{C}_{\text {org }}$ was found in the sediment, especially in the Ea-dominated seascapes. In the Cym/Th-dominated seascapes, on the other hand, the proportion of unvegetated area was positively related to sedimentary $\mathrm{C}_{\text {org }}$ content, which could be explained by their location in vast sand flats and the patchy occurrence of this seagrass community in the bay. Any occurring organic material (autochthonously- or allochthonously-produced) will most likely be trapped and end up in the seagrass patches rather than in the surrounding unvegetated areas. In fact, high patch richness had generally a negative influence on the sedimentary $\mathrm{C}_{\text {org }}$ content, even though this picture was not evident in the community-specific models, where such relationships might be masked by the fact that many habitat types may be missing in the seascape units (i.e. the $1 \mathrm{~km}$ buffer zones). We observed that larger continuous seagrass areas may have a greater potential to contain higher amount of $\mathrm{C}_{\text {org }}$ than more diverse or patchy areas, as the autochthonous plant material is more likely to end up within a vast meadow (Ricart et al. 2017). Such a habitat-area relationship has previously 
been suggested in the western Indian Ocean region (Gullström et al. 2018). The edges of habitat patches measured as perimeter-area relationships also seem to have an important but contrasting (species- or community-specific) influence on the levels of $\mathrm{C}_{\text {org }}$ in seagrass sediment, as seen when comparing the models of the Cym/Th- (negative relation) and Tc(positive relation) dominated seascapes. The model performance of the Cym/Th-dominated seascapes hence harmonizes with the continuous seagrass area assumption (emphasized by Gullström et al. 2018), as a lower perimeter-area relationship seems to generate a higher $\mathrm{C}_{\text {org }}$ content in the sediment. Patches with high perimeter-area relationship may indicate fragmentation into small patches, which may negatively influence the sedimentary $\mathrm{C}_{\text {org }}$ content in seagrass meadows (Ricart et al. 2015b, 2017; Oreska et al. 2017; Gullström et al. 2018). The opposite influence seen in the $T c$-dominated seascapes cannot be explained by the same assumption, but rather be a result of the position and shape of $T c$-meadows as narrow strips at the edge of the seagrass zonation towards the open sea and/or the large perimeter-area ratio of surrounding habitats in the seascape units.

The most important distances-based metrics were found along the land-to-sea gradient, especially those assessing the association to deforested mangrove. In general, the models revealed that the sedimentary $\mathrm{C}_{\text {org }}$ content in the upper $25 \mathrm{~cm}$ of sediment was higher in closer proximity to the deforested area and lower closer to the open ocean. Such land-sea linkages have recently been studied in estuarine environments (Ricart et al. 2020), with the findings showing a high proportion of land-based organic carbon in seagrass sediment. The land-sea coupling seen in our study can have several explanations that act in combination. First, outwelling of organic matter and $\mathrm{C}_{\text {org }}$ from cleared mangrove areas may have occurred. Second, the complex network of rivers, mangrove creeks and channels in the vicinity of the deforested mangrove may increase the transport of organic material from land and from the cleared mangroves. Third, the seagrass seascapes in the area adjacent to the cleared mangrove are dominated by $E a$, where higher sedimentary $\mathrm{C}_{\text {org }}$ levels were observed. Fourth, the zone between the intact mangrove and the open ocean was slightly narrower compared to the zone outside the deforested mangrove, wherefore seagrass seascapes in this area may be influenced by closer proximity to both mangrove and open ocean. Recently, Arias-Ortiz et al. (2020) showed that $20 \%$ of the soil carbon stocks in the upper meter of cleared mangroves in Tsimipaika Bay have been lost in the last 10 years due to deforestation through several pathways, including $\mathrm{CO}_{2}$ emissions and DOC export, which may have implications for adjacent ecosystems such as seagrass meadows. We could, however, not observe any influence of proximity to cleared mangrove area on carbon stocks (down to one meter depth) of the seagrass sediment. One reason may be that mangrove deforestation is a relatively recent disturbance (occurring since the 1990s in the region), hence the integration of $\mathrm{C}_{\text {org }}$ stocks in the upper meter may hide any difference in $\mathrm{C}_{\text {org }}$ inputs during recent times, which are expected to have an effect in the upper layers only. Additionally, we did not observe recent net sediment accumulation at these sites as shown by the ${ }^{210} \mathrm{~Pb}$ data (Supplementary Fig. S2), suggesting that these long seagrass cores are not representative of recent sediment dynamics. The lack of excess ${ }^{210} \mathrm{~Pb}$ is consistent with intense sediment resuspension and transport, usually observed in high-energy environments generating well-mixed sediments (Arias-Ortiz et al. 2018). The sampling location of some of the long cores may be a reason for a low $\mathrm{C}_{\text {org }}$ content; we speculate that the factors "closeness to channels" (with higher water flow) and "focal area size" could downplay the factor "closeness to mangrove". But most likely, the lower number of long cores together with the high variability in $\mathrm{C}_{\text {org }}$ content observed within them, might mask some of the patterns observed in the short cores, the number of which is 15-fold larger and cover a more widespread area across the bay. However, we did see clear differences in $\mathrm{C}_{\text {org }}$ content and stocks between the vegetated and unvegetated sediments in both long and short cores, suggesting that seagrasses may play an important role in preserving the $\mathrm{C}_{\text {org }}$ already present in the sediments.

Considering the influence of plant traits, our findings suggest that seagrass structural complexity and cover influence the plants' efficiency to sequester or trap allochthonous organic material moving within the seascape. The PLS and PCA models showed that seagrass canopy height (mainly driven by the variation in shoot height of $E a$ ) and cover positively influenced the sedimentary $\mathrm{C}_{\text {org }}$ content and that many seagrasses may have strong effects on carbon sequestration through their high primary productivity. This was 
most likely due to high seagrass plant biomasses and their effecient ability to trap material from surrounding areas (Samper-Villarreal et al. 2016). Sediment density seems also to have a significant role for $\mathrm{C}_{\text {org }}$ levels in seagrass habitats, as shown by the models in this study and by earlier studies elsewhere (e.g. Avnimelech et al. 2001; Dahl et al. 2016b, 2020a; Röhr et al. 2018). High $C_{\text {org }}$ content is generally associated with low sediment density since organic material has a lower weight compared to minerogenic particles (Winterwerp and van Kesteren 2004) and a higher water content (Avnimelech et al. 2001). Other sediment characteristics, such as mud content and degree of grain size sorting, are known to positively influence the sedimentary $\mathrm{C}_{\text {org }}$ content and inversely affecting sediment density (Röhr et al. 2018). Both grain size distribution and sediment density are linked to the hydrodynamic exposure, where sheltered areas have lower sediment density and higher mud content (Dahl et al. 2020b) as these sediment bed types are more easily eroded (Jacobs et al. 2011). Sediment density in our study was negatively correlated to sedimentary $\mathrm{C}_{\text {org }}$ in the seagrass seascapes dominated by the higher growing climax species (i.e. $E a$ and $T c$ ), which was potentially due to the higher organic matter content in the sediment of these larger seagrass species compared to the $C y m / T h$-dominated sediment, and that larger species may have a higher potential for reducing the water flow with the canopy. The negative influence of seagrass shoot density on the $\mathrm{C}_{\text {org }}$ content may seem contradictory since increasing shoot densities normally slows the water flow (Peterson et al. 2004) but is likely due to the inverse relationship between shoot density and canopy height (seen e.g. in Gullström et al. 2006). This means that the $C_{\text {org }}$ content, especially in Ea-dominated meadows, was higher in areas with high seagrass canopies while low shoot density. In addition, the higher $E a$ canopy seen outside the deforested mangrove area, where the water often was more turbid, may be a plant response to limited light conditions. In contrast to $E a$-dominated meadows, very dense $T c$-dominated meadows may limit allochthonous carbon to reach the underlying sediment. Overall, our study confirms that both landscape processes and plant-sediment properties of seagrass habitats play an important role for carbon accumulation in the sediments, and thus for these areas' carbon sink function.
Cross-habitat connectivity and influence of altered land-use

In coastal environments, organic matter is regularly transferred across habitat boundaries (Bouillon and Connolly 2009; Hyndes et al. 2014), which depends on different direct and indirect mechanisms of carbon transfer at seascape scale (Huxham et al. 2018). For instance, exchange of carbon (e.g. litter, particulate and dissolved organic and inorganic carbon) between vegetated coastal/terrestrial areas and seagrass meadows can be substantial (Maher et al. 2013). Global estimates show that $50-72 \%$ of the organic carbon pool of the surface sediment in seagrass habitats can originate from terrestrial vegetation or other allochthonous sources (Gacia et al. 2002; Kennedy et al. 2010). Our study showed a high mean proportion of allochthonous organic carbon originating either from mangrove/terrestrial areas or as SPOM that exceeds $70 \%$ in the seagrass sediment, although the mean levels varied among seascapes (from 10 to 59\%) and across seagrass community types $(71 \%$ for all seagrasses, $77 \%$ for $E a, 68 \%$ for $C y m / T h$ and $58 \%$ for $T c$ ). Such high contribution of allochthonous material to carbon accumulation and storage has been seen in other tropical seagrass areas (e.g. Chen et al. 2017; Ricart et al. 2020). Carbon subsidies from mangroves to other shallow-water habitats (such as seagrass meadows) can occur due to multiple interconnecting factors, such as rainfall creating runoff (Huxham et al. 2018), hydrodynamic and tidal forces (Slim et al. 1996), animal movement (Kneib 1997) and/or major plant systems' efficiency in trapping carbon (Kennedy et al. 2010). The influence of seascape configuration may be changed with major alterations in land use, as has occurred in an extensive part of our studied embayment. The variability in compositions of $\mathrm{C}_{\mathrm{org}}$ from the isotopic analysis shows that transfer of carbon from intact mangroves to seagrass meadows differed from the observations in seagrass meadows next to the deforested areas, where the major source of carbon was mangrove-originated. Patterns of carbon movement and exchange in this coastal environment seem to be driven by a gradient across the land-sea interface, with higher presence of mangrove/landoriginated carbon in seagrass meadows at closer distance to mangrove (both intact- and deforestedareas) and farther from the open sea. Even though studies in areas where mangrove and seagrass occur 
next to each other have showed high carbon subsidies from mangrove to seagrass areas (e.g. Gonneea et al. 2004; Kennedy et al. 2010; Gullström et al 2018), our results indicate that clearing of mangroves increases such outwelling effect, inducing a shift in carbon transfer from mangrove areas to adjacent seagrass meadows. Further, our results also show that closeness to channels can reduce sedimentary $\mathrm{C}_{\text {org }}$ in seagrass sediment, which is most likely due to erosion by increased hydrodynamic forces (Dahl et al. 2018).

\section{Concluding remarks}

This study emphasized that the carbon sink function of tropical seagrass meadows is driven by multiscale spatial determinants, including landscape configuration, patch heterogeneity, within-patch attributes (plant-sediment properties), land-use change and land-to-sea gradients.

Such information regarding spatial heterogeneity is of fundamental importance to understand complex patterns and processes in ecology (Pickett and Cadenasso 1995). In blue carbon science, understanding spatial patterns of variability and what is driving the observed patterns is important to successfully identify carbon sink hotspots and to avoid double-counting in order to develop conservation prioritizations and blue carbon projects.

Acknowledgements The study is part of the 4-year Blue Forests Project, initiated by the United Nations Environment Programme (UNEP) and partly funded by the Global Environment Facility (GEF). We thank the Swedish International Development Cooperation Agency-Sida, marine bilateral programme for funding the participation of ROI and LDL. Funding was provided to PM through an Australian Research Council LIEF Project (LE170100219) and by the Generalitat de Catalunya (Grant 2017 SGR-1588). This work is contributing to the ICTA "Unit of Excellence" (MinECo, MDM2015-0552). Funding for MD was provided by the Bolin Centre for Climate Research. AA-O was supported by "Obra Social la Caixa" (LCF/BQ/ES14/10320004) and subsequently by the NOAA C\&GC Postdoctoral Fellowship administered by UCAR-CPAESS (\#NA18NWS4620043B). The IAEA is grateful for the support provided to its Environment Laboratories by the Government of the Principality of Monaco. Thanks to Michel Goffstron for helping out with logistics and assistance in field. Thanks also to our eminent boat captain Tombo and boat crew Dominique for their excellent navigation and boat handling in the complex tidal area and for their help in field. Further, we want to thank
Soa Mahatoly, who is an excellent chef that has been feeding the whole crew during this field survey.

Funding Open access funding provided by University of Gothenburg.

Open Access This article is licensed under a Creative Commons Attribution 4.0 International License, which permits use, sharing, adaptation, distribution and reproduction in any medium or format, as long as you give appropriate credit to the original author(s) and the source, provide a link to the Creative Commons licence, and indicate if changes were made. The images or other third party material in this article are included in the article's Creative Commons licence, unless indicated otherwise in a credit line to the material. If material is not included in the article's Creative Commons licence and your intended use is not permitted by statutory regulation or exceeds the permitted use, you will need to obtain permission directly from the copyright holder. To view a copy of this licence, visit http://creativecommons.org/licenses/by/4.0/.

\section{References}

Alongi DM, Boto KG, Tirendi F (1989) Effect of exported mangrove litter on bacterial productivity and dissolved organic carbon fluxes in adjacent tropical nearshore sediments. Mar Ecol Prog Ser 56:133-144

Arias-Ortiz A, Masqué P, Garcia-Orellana J, Serrano O, Mazarrasa I, Marbà N, Lovelock CE, Lavery PS, Duarte CM (2018) Reviews and syntheses: ${ }^{210} \mathrm{~Pb}$-derived sediment and carbon accumulation rates in vegetated coastal ecosystems: setting the record straight. Biogeoscience 15:6791-6818

Arias-Ortiz A, Masqué P, Glass L, Benson L, Kennedy H, Duarte CM, García Orellana J, Benítez Nelson CR, Humphries MS, Ratefinjanahary I, Ravelonjatovo J, Lovelock CE (2020) Losses of soil organic carbon with deforestation in mangroves of Madagascar. Ecosystems. https://doi.org/10.1007/s10021-020-00500-z

Avnimelech Y, Ritvo G, Meijer LE, Kochba M (2001) Water content, organic carbon and dry bulk density in flooded sediments. Aquac Eng 25:25-33

Belshe EF, Hoeijmakers D, Herran N, Mtolera M, Teichberg M (2018) Seagrass community-level controls over organic carbon storage are constrained by geophysical attributes within meadows of Zanzibar, Tanzania. Biogeoscience 15:4609-4626

Bouillon S, Connolly RM (2009) Carbon exchange among tropical coastal ecosystems. In: Nagelkerken I (ed) Ecological connectivity among tropical coastal ecosystems. Springer, Dordrecht, pp 45-70

Chen G, Azkab MH, Chmura GL, Chen S, Sastrosuwondo P, Ma Z, Dharmawan IWE, Yin X, Chen B (2017) Mangroves as a major source of soil carbon storage in adjacent seagrass meadows. Sci Rep 7:42406 
Crossland CJ, Kremer HH, Lindeboom H, Marshall Crossland JI, Le Tissier MDA (2005) Coastal fluxes in the anthropocene. Springer, Berlin

Dahl M, Asplund ME, Björk M, Deyanova D, Iseaus M, Infantes E, Nyström Sandman A, Gullström M (2020a) The influence of hydrodynamic exposure on carbon storage and nutrient retention in eelgrass (Zostera marina L.) meadows on the Swedish Skagerrak coast. Sci Rep 10:13666

Dahl M, Asplund ME, Deyanova D, Franco JN, Koliji A, Infantes E, Perry D, Björk M, Gullström M (2020b) High seasonal variability in sediment carbon stocks of coldtemperate seagrass meadows. J Geophys Res 125:e2019JG005430

Dahl M, Deyanova D, Gütschow S, Asplund ME, Lyimo LD, Karamfilov V, Santos R, Björk M, Gullström M (2016a) Sediment properties as important predictors of carbon storage in Zostera marina meadows: a comparison of four European areas. PLoS ONE 11:e0167493

Dahl M, Deyanova D, Lyimo LD, Näslund J, Samuelsson GS, Mtolera MSP, Björk M, Gullström M (2016b) Effects of shading and simulated grazing on carbon sequestration in a tropical seagrass meadow. J Ecol 104:654-664

Dahl M, Infantes E, Clevesjö R, Linderholm HW, Björk M, Gullström M (2018) Increased current flow enhances the risk of organic carbon loss from Zostera marina sediments: insights from a flume experiment. Limnol Oceanogr 63:2793-2805

Duarte CM, Krause-Jensen D (2017) Export from seagrass meadows contributes to marine carbon sequestration. Front Mar Sci 4:13

Duarte CM, Marbà N, Gacia E, Fourqurean JW, Beggins J, Barrón C, Apostolaki ET (2010) Seagrass community metabolism: assessing the carbon sink capacity of seagrass meadows. Global Biogeochem Cycl 24:GB4032

Fan B, Li Y, Pavao-Zuckerman M (2020) The dynamics of landsea-scape carbon flow can reveal anthropogenic destruction and restoration of coastal carbon sequestration. Landsc Ecol. https://doi.org/10.1007/s10980-020-01148-9

Fischer J, Lindenmayer DB (2007) Landscape modification and habitat fragmentation: a synthesis. Global Ecol Biogeogr 16:265-280

Foley JA, DeFries R, Asner GP, Barford C, Bonan G, Carpenter SR, Chapin FS, Coe MT, Daily GC, Gibbs HK, Helkowski JH, Holloway T, Howard EA, Kucharik CJ, Monfreda C, Patz JA, Prentice IC, Ramankutty N, Snyder PK (2005) Global consequences of land use. Science 309:570-574

Fourqurean JW, Duarte CM, Kennedy H, Marbà N, Holmer M, Mateo MA, Apostolaki ET, Kendrick GA, Krause-Jensen D, McGlathery KJ, Serrano O (2012) Seagrass ecosystems as a globally significant carbon stock. Nat Geosci 5:505-509

Gacia E, Duarte CM, Middelburg JJ (2002) Carbon and nutrient deposition in a Mediterranean seagrass (Posidonia oceanica) meadow. Limnol Oceanogr 47:23-32

Giri C (2011) National-level mangrove cover data-sets for 1990, 2000 and 2010. United States Geological Survey, Sioux Falls

Githaiga MN, Kairo JG, Gilpin L, Huxham M (2017) Carbon storage in the seagrass meadows of Gazi Bay, Kenya. PLoS ONE 12:e0177001
Glew JR, Smol JP, Last WM (2002) Sediment core collection and extrusion. In: Last WM, Smol JP (eds) Tracking environmental change using lake sediments. Developments in Paleoenvironmental Research, vol 1. Springer, Dordrecht, pp 73-105

Gonneea ME, Paytan A, Herrera-Silveira JA (2004) Tracing organic matter sources and carbon burial in mangrove sediments over the past 160 years. Estuar Coast Shelf Sci 61:211-227

Grober-Dunsmore R, Pittman SJ, Caldow C, Kendall MS, Frazer TK (2009) A landscape ecology approach for the study of ecological connectivity across tropical marine seascapes. In: Nagelkerken I (ed) Ecological connectivity among tropical coastal ecosystems. Springer, New York, pp 493-530

Gullström M, de la Torre CM, Bandeira SO, Björk M, Dahlberg M, Kautsky N, Rönnbäck P, Öhman MC (2002) Seagrass ecosystems in the Western Indian Ocean. Ambio 31:588-596

Gullström M, Lundén B, Bodin M, Kangwe J, Öhman MC, Mtolera MSP, Björk M (2006) Assessment of changes in the seagrass-dominated submerged vegetation of tropical Chwaka Bay (Zanzibar) using satellite remote sensing. Estuar Coast Shelf Sci 67:399-408

Gullström M, Lyimo LD, Dahl M, Samuelsson GS, Eggertsen M, Anderberg E, Rasmusson LM, Linderholm HW, Knudby A, Bandeira S, Nordlund LM, Björk M (2018) Blue carbon storage in tropical seagrass meadows relates to carbonate stock dynamics, plant-sediment processes, and landscape context: insights from the Western Indian Ocean. Ecosystems 21:551-566

Gullström M, Dahl M, Lindén O, Vorhies F, Forsberg S, Ismail RO, Björk M (2021) Coastal blue carbon stocks in Tanzania and Mozambique: support for climate adaptation and mitigation actions. IUCN, Gland, p 83

Hamilton SE, Casey D (2016) Creation of a high spatio-temporal resolution global database of continuous mangrove forest cover for the 21 st century (CGMFC-21). Global Ecol Biogeogr 25:729-738

Howard J, Hoyt S, Isensee K, Telszewski M, Pidgeon E (2014) Coastal blue carbon: methods for assessing carbon stocks and emissions factors in mangroves, tidal salt marshes, and seagrass meadows. Conservation International, Intergovernmental Oceanographic Commission of UNESCO, International Union for Conservation of Nature, Arlington

Huxham M, Whitlock D, Githaiga M, Dencer-Brown A (2018) Carbon in the coastal seascape: how interactions between mangrove forests, seagrass meadows and tidal marshes influence carbon storage. Curr For Rep 4:101-110

Hyndes GA, Nagelkerken I, McLeod RJ, Connolly RM, Lavery PS, Vanderklift MA (2014) Mechanisms and ecological role of carbon transfer within coastal seascapes. Biol Rev 89:232-254

Jacobs W, Le Hir P, Van Kesteren W, Cann P (2011) Erosion threshold of sand-mud mixtures. Cont Shelf Res 31:14-25

Jones TG, Ratsimba HR, Carro A, Ravaoarinorotsihoarana L, Glass L, Teoh M, Benson L, Cripps G, Giri C, Zafindrasilivonona $\mathrm{B}$, Raherindray $\mathrm{R}$, Andriamahenina $\mathrm{Z}$, Andriamahefazafy M (2016) The mangroves of Ambanja and Ambaro Bays, northwest Madagascar: historical dynamics, current status and deforestation mitigation 
strategy. In: Diop S, Scheren P, Ferdinand Machiwa J (eds) Estuaries: a lifeline of ecosystem services in the Western Indian Ocean. Estuaries of the world. Springer, Dordrecht, pp 67-85

Jones TG, Ratsimba HR, Ravaoarinorotsihoarana L, Cripps G, Bey A (2014) Ecological variability and carbon stock estimates of mangrove ecosystems in northwestern Madagascar. Forests 5:177-205

Juma GA, Magana AM, Michael GN, Kairo JG (2020) Variation in seagrass carbon stocks between tropical estuarine and marine mangrove-fringed creeks. Front Mar Sci 7:696

Kennedy H, Beggins J, Duarte CM, Fourqurean JW, Holmer M, Marbà N, Middelburg JJ (2010) Seagrass sediments as a global carbon sink: isotopic constraints. Global Biogeochem Cycl 24:GB4026

Kennedy P, Kennedy H, Papadimitriou S (2005) The effect of acidification on the determination of organic carbon, total nitrogen and their stable isotopic composition in algae and marine sediment. Rapid Commun Mass Spectrom 19:1063-1068

Kneib RT (1997) The role of tidal marshes in the ecology of estuarine nekton. Oceanogr Mar Biol Annu Rev 35:163-220

Kristensen E, Bouillon S, Dittmard T, Marchand C (2008) Organic carbon dynamics in mangrove ecosystems: a review. Aquat Bot 89:201-219

Lamb AL, Wilson GP, Leng MJ (2006) A review of coastal palaeoclimate and relative sea-level reconstructions using $\delta 13 \mathrm{C}$ and $\mathrm{C} / \mathrm{N}$ ratios in organic material. Earth-Sci Rev 75:29-57

Lavery PS, Mateo M-Á, Serrano O, Rozaimi M (2013) Variability in the carbon storage of seagrass habitats and its implications for global estimates of blue carbon ecosystem service. PLoS ONE 8:e73748

Lepoint G, Dauby P, Gobert S (2004) Applications of C and N stable isotopes to ecological and environmental studies in seagrass ecosystems. Mar Pollut Bull 49:887-891

Levene H (1960) Robust tests for equality of variances. In: Olkin I, Ghurye SG, Hoeffding W, Madow WG, Mann HB (eds) Contributions to probability and statistics: essays in honor of Harold Hotelling. Stanford University Press, Stanford, pp 278-292

Maher DT, Santos IR, Golsby-Smith L, Gleeson J, Eyre BD (2013) Groundwater-derived dissolved inorganic and organic carbon exports from a mangrove tidal creek: the missing mangrove carbon sink? Limnol Oceanogr 58:475-488

Marbà N, Holmer M, Gacia E, Barrón C (2006) Seagrass and coastal biogeochemistry. In: Larkum WD, Orth RJ, Duarte CM (eds) Seagrasses: Biology, ecology and conservation. Springer, Dordrecht, pp 135-292

Mateo MA, Romero J, Pérez M, Littler MM, Littler DS (1997) Dynamics of millenary organic deposits resulting from the growth of the Mediterranean seagrass Posidonia oceanica. Estuar Coast Shelf Sci 44:103-110

McKenna SA, Allen GR (2005) A rapid marine biodiversity assessment of the coral reefs of Northwest Madagascar. The Rapid Assessment Program Bulletin of Biological Assessment 31, Conservation International, Washington, DC
Mcleod E, Chmura GL, Bouillon S, Salm R, Björk M, Duarte CM, Lovelock CE, Schlesinger WH, Silliman BR (2011) A blueprint for blue carbon: toward an improved understanding of the role of vegetated coastal habitats in sequestering $\mathrm{CO}_{2}$. Front Ecol Environ 9:552-560

Miyajima T, Hori M, Hamaguchi M, Shimabukuro H, Adachi H, Yamano H, Nakaoka M (2015) Geographic variability in organic carbon stock and accumulation rate in sediments of East and Southeast Asian seagrass meadows. Glob Biogeochem Cycl 29:397-415

Najjar RG, Herrmann M, Alexander R, Boyer EW, Burdige DJ, Butman D, Cai W-J, Canuel EA, Chen RF, Friedrichs MAM, Feagin RA, Griffith PC, Hinson AL, Holmquist JR, Hu X, Kemp WM, Kroeger KD, Mannino A, McCallister SL, McGillis WR, Mulholland MR, Pilskaln CH, Salisbury J, Signorini SR, St-Laurent P, Tian H, Tzortziou M, Vlahos P, Wang ZA, Zimmerman RC (2018) Carbon budget of tidal wetlands, estuaries, and shelf waters of Eastern North America. Glob Biogeochem Cycl 32:389-416

Olesen KLL, Falinski KA, Audas D, Coccia-Schillo S, Groves P, Teneva L, Pittman SJ (2018) Linking landscape and seascape conditions: science, tools and management. In: Pittman SJ (ed) Seascape ecology. Wiley, Oxford, pp 319-364

Oreska MPJ, McGlathery KJ, Porter JH (2017) Seagrass blue carbon spatial patterns at the meadow-scale. PLoS ONE 12:e176630

Pendleton L, Donato DC, Murray BC, Crooks S, Jenkins WA, Sifleet S, Craft C, Fourqurean JW, Kauffman JB, Marba N, Megonigal P, Pidgeon E, Herr D, Gordon D, Baldera A (2012) Estimating global 'blue carbon' emissions from conversion and degradation of vegetated coastal ecosystems. PLoS ONE 7:e43542

Pastick NJ, Duffy P, Genet H, Scott Rupp T, Wylie BK, Johnson $\mathrm{KD}$, Jorgenson MT, Bliss N, McGuire AD, Jafarov EE, Knight JF (2017) Historical and projected trends in landscape drivers affecting carbon dynamics in Alaska. Ecol Appl 27:1383-1402

Peterson CH, Luettich RA Jr, Micheli F, Skilleter GA (2004) Attenuation of water flow inside seagrass canopies of differing structure. Mar Ecol Prog Ser 268:81-92

Phang VXH, Chou LM, Friess DA (2015) Ecosystem carbon stocks across a tropical intertidal habitat mosaic of mangrove forest, seagrass meadow, mudflat and sandbar. Earth Surf Proc Landf 40:1387-1400

Pickett STA, Cadenasso ML (1995) Landscape ecology: spatial heterogeneity in ecological systems. Science 269:331-334

Pittman SJ, Rodwell LD, Shellock RJ, Williams M, Attrill MJ, Bedford J, Curry K, Fletcher S, Galla SC, Lowther J, McQuatters-Gollop A, Moseley KL, Rees SE (2019) Marine parks for coastal cities: a concept for enhanced community well-being, prosperity and sustainable city living. Mar Pol 103:160-171

Regnier P, Friedlingstein P, Ciais P, Mackenzie FT, Gruber N, Janssens IA, Laruelle GG, Lauerwald R, Luyssaert S, Andersson AJ, Arndt S, Arnosti C, Borges AV, Dale AW, Gallego-Sala A, Goddéris Y, Goossens N, Hartmann J, Heinze C, Ilyina T, Joos F, LaRowe DE, Leifeld J, Meysman FJR, Munhoven G, Raymond PA, Spahni R, Suntharalingam P, Thullner M (2013) Anthropogenic 
perturbation of the carbon fluxes from land to ocean. Nat Geosci 6:597-607

Ricart AM, Dalmau A, Pérez M, Romero J (2015a) Effects of landscape configuration on the exchange of materials in seagrass ecosystems. Mar Ecol Prog Ser 532:89-100

Ricart AM, Pérez M, Romero J (2017) Landscape configuration modulates carbon storage in seagrass sediments. Estuar Coast Shelf Sci 185:69-76

Ricart AM, York PH, Bryant CV, Rasheed MA, Ierodiaconou D, Macreadie PI (2020) High variability of blue carbon storage in seagrass meadows at the estuary scale. Sci Rep 10:1-12

Ricart AM, York PH, Rasheed MA, Pérez M, Romero J, Bryant CV, Macreadie PI (2015b) Variability of sedimentary organic carbon in patchy seagrass landscapes. Mar Poll Bull 100:476-482

Röhr E, Holmer M, Baum JK, Björk M, Chin D, Chalifour L, Cimon S, Cusson M, Dahl M, Deyanova D, Duffy JE, Eklöf JS, Geyer JK, Griffin JN, Gullström M, Hereu CM, Hori M, Hovel KA, Hughes AR, Jorgensen P, Kiriakopolos S, Moksnes P-O, Nakaoka M, O'Connor MI, Peterson B, Reiss K, Reynolds PL, Rossi F, Ruesink J, Santos R, Stachowicz JJ, Tomas F, Lee K-S, Unsworth RKF, Boström C (2018) Blue carbon storage capacity of temperate eelgrass (Zostera marina) meadows. Global Biogeochem Cycl 32:1457-1475

Saintilan N, Rogers K, Mazumder D, Woodroffe C (2013) Allochthonous and autochthonous contributions to carbon accumulation and carbon store in southeastern Australian coastal wetlands. Estuar Coast Shelf Sci 128:84-92

Samper-Villarreal J, Lovelock CE, Saunders MI, Roelfsema C, Mumby PJ (2016) Organic carbon in seagrass sediments is influenced by seagrass canopy complexity, turbidity, wave height, and water depth. Limnol Oceanogr 61:938-952

Serrano O, Lovelock CE, Atwood TB, Macreadie PI, Canto R, Phinn S, Arias-Ortiz A, Bai L, Baldock J, Bedulli C, Carnell P, Connolly RM, Donaldson P, Esteban A, Lewis CJE, Eyre BD, Hayes MA, Horwitz P, Hutley LB, Kavazos CRJ, Kelleway JJ, Kendrick GA, Kilminster K, Lafratta A, Lee S, Lavery PS, Maher DT, Marbà N, Masque P, Mateo MA, Mount R, Ralph PJ, Roelfsema C, Rozaimi M, Ruhon R, Salinas C, Samper-Villarreal J, Sanderman J, Sanders CJ, Santos I, Sharples C, Steven ADL, Cannard T, TrevathanTackett SM, Duarte CM (2019) Australian vegetated coastal ecosystems as global hotspots for climate change mitigation. Nat Commun 10:4313

Sharp Z (2005) Principles of stable isotope geochemistry. Prentice Hall, Upper Saddle River
Short F, Carruthers T, Dennison W, Waycott M (2007) Global seagrass distribution and diversity: a bioregional model. J Exp Mar Biol Ecol 350:3-20

Slim FJ, Hemminga MA, E. Cocheret De La Morinière E, Van Der Velde G, (1996) Tidal exchange of macrolitter between a mangrove forest and adjacent seagrass beds (Gazi Bay, Kenya). Netherl J Aquat Ecol 30:119-128

Sloan NA, Vance-Borland K, Ray GCG (2007) Fallen between the cracks: conservation linking land and sea. Conserv Biol 21:897-898

Smith SV (1981) Marine macrophytes as a global carbon sink. Science 211:838-840

Spalding M, Kainuma M, Collins L (2010) World atlas of mangroves. Earthscan, London

Trevathan-Tackett SM, Wessel C, Cebrián J, Ralph PJ, Masqué P, Macreadie PI (2018) Effects of small-scale, shadinginduced seagrass loss on blue carbon storage: implications for management of degraded seagrass ecosystems. J Appl Ecol 55:1351-1359

Turner MG (1989) Landscape ecology: the effect of pattern on process. Ann Rev Ecol Syst 20:171-197

Waycott M, Duarte CM, Carruthers TJB, Orth RJ, Dennison WC, Olyarnik S, Ainsley C, Fourqurean JW, Heck KL, Hughes AR, Kendrick GA, Kenworthy WF, Short FT, Williams SL (2009) Accelerating loss of seagrasses across the globe threatens coastal ecosystems. Proc Natl Acad Sci USA 106:12377-21238

Wiens JA (1995) Landscape mosaics and ecological theory. In: Hansson L, Fahrig L, Merriam G (eds) Mosaic landscapes and ecological processes. Springer, Dordrecht

Winterwerp JC, van Kesteren WGW (2004) Introduction to the physics of cohesive sediment in the marine environment. In: Winterwerp JC, van Kesteren WGW (eds) Developments in sedimentology series 56. Elsevier, Amsterdam

Wold S, Sjöström M, Eriksson L (2001) PLS-regression: a basic tool of chemometrics. Chemom Intell Lab Syst 58:109-130

Wu J (2004) Effects of changing scale on landscape pattern analysis: scaling relations. Landsc Ecol 19:125-138

Wu J, Hobbs R (2002) Key issues and research priorities in landscape ecology: an idiosyncratic synthesis. Landsc Ecol $17: 355-365$

Publisher's Note Springer Nature remains neutral with regard to jurisdictional claims in published maps and institutional affiliations. 